\title{
Interdecadal variations in ENSO influences on Northwest Pacific -East Asian early summertime climate simulated in CMIP5 models
}

Kaiming $\mathrm{Hu}^{1}$, Gang Huang ${ }^{2}$, Xiao-Tong Zheng ${ }^{3}$, Shang-Ping Xie ${ }^{4}, \mathrm{Xia}{ }^{1}$, Yan $\mathrm{Du}^{5}$, and $\mathrm{Lin} \mathrm{Liu}^{6}$

${ }^{1}$ Center for Monsoon System Research, Institute of Atmospheric Physics, Chinese Academy of Sciences, Beijing, China

${ }^{2}$ Key Laboratory of Regional Climate-Environment for East Asia, Institute of Atmospheric Physics, Chinese Academy of Sciences, Beijing, China

${ }^{3}$ Physical Oceanography Laboratory and Key Laboratory of Ocean-Atmosphere Interaction and Climate in Universities of Shandong, Ocean University of China

${ }^{4}$ Scripps Institution of Oceanography, University of California at San Diego, La Jolla, California; Physical Oceanography Laboratory, Ocean University of China, Qingdao, China; International Pacific Research Center and the Department of Meteorology, University of Hawaii at Manoa, Honolulu, Hawaii

${ }^{5}$ State Key Laboratory of Tropical Oceanography, South China Sea Institute of Oceanology, Chinese Academy of Sciences, Guangzhou, China

${ }^{6}$ First Institute of Oceanography, State Oceanic Administration, China

\section{Submitted to Journal of Climate,}

Corresponding author address: Gang Huang, RCE-TEA/IAP/CAS, P.O. Box 9804, Beijing 100029, China; E-mail: hg@mail.iap.ac.cn 


\begin{abstract}
The present study investigates interdecadal modulations of the El Niño-Southern Oscillation (ENSO) influence on the climate of the Northwest Pacific (NWP) and East Asia (EA) in early boreal summer following a winter ENSO event, based on 19 Coupled Model Intercomparison Project Phase 5 (CMIP5) simulations. In the historical run, 8 out of 19 models capture a realistic relationship between ENSO and NWP early summer climate - an anomalous anticyclone develops over the NWP following a winter El Niño event-and the interdecadal modulations of this correlation. During periods when the association between ENSO and NWP early summer climate is strong, ENSO variance, and ENSO-induced anomalies of summer sea surface temperature (SST) and tropospheric temperature over the tropical Indian Ocean (TIO) all strengthen relative to periods when the association is weak.

In future projections with Representative Concentration Pathways 4.5 and 8.5, the response of TIO SST, tropospheric temperature and NWP anomalous anticyclone to ENSO all strengthens regardless ENSO amplitude change. In a warmer climate, low-level specific humidity response to interannual SST variability strengthens following the Clausius-Clapeyron equation. The resultant intensification of tropospheric temperature response to interannual TIO warming is suggested as the mechanism for the strengthened ENSO effect on NWP/EA summer climate.
\end{abstract}




\section{Introduction}

Summer is the major rainy season for the subtropical Northwest Pacific (NWP) and East Asia (EA). Climate variability during summer is of great socioeconomic importance for populated regions of East Asia. El Niño-Southern Oscillation (ENSO) is an important factor for summertime climate variability in the subtropical NWP/EA (Huang and Wu 1989). In summer following an El Niño event, precipitation tends to decrease in the subtropical NWP and increase over eastern China and Japan (Wang et al. 2000; Wu et al. 2003).

An anomalous anticyclone often forms over the subtropical NWP following an El Niño event (Zhang et al. 1996), which is considered as a bridge of teleconnection from ENSO to the NWP/EA (Wang et al. 2000). On one hand, the anomalous anticyclone weakens the NWP summer monsoon by suppressing convection; on the other hand, the anomalous anticyclone enhances the East Asian summer monsoon by bringing moisture from the tropical ocean (Chang et al. 2000) and exciting the Pacific-Japan (PJ; Nitta 1987)/East Asia-Pacific (EAP; Huang and Wu 1989) teleconnection pattern. In Addition, the anomalous anticyclone can cause anomalous warm summer in southern China and cool summer in northeastern China (Hu et al. 2011; 2012).

Wang et al. (2003) suggested that the El Niño-triggered NWP anomalous anticyclone induces SST cooling to its east by enhancing evaporation, which in turn reinforces the anomalous anticyclone by generating a descending atmospheric Rossby wave. The positive air-sea positive feedback helps persist and enhance the NWP anomalous anticyclone (Xiang et al. 2013). As a complementary mechanism, Xie et al. (2009) reported that the El Niño-induced tropical Indian Ocean (TIO) warming contributes to the NWP anticyclone anomalies. The El Niño-induced TIO warming forces a Matsuno (1966)-Gill (1980) pattern in tropospheric temperature; excites a warm tropospheric Kelvin wave propagating into the western Pacific; induces Ekman divergences in the subtropical NWP to suppress convection; and triggers an surface anomalous anticyclone in the NWP. The process is called as the Indian Ocean capacitor effect. Based on model simulations, Lau and Nath (2009) and Wu et al. 
(2010) suggested that both the NWP air-sea interaction and the TIO capacitor effect contribute to the formation and maintenance of the NWP anticyclonic anomalies.

With accumulation of observations, evidence is emerging that ENSO teleconnection to NWP/EA summer climate is not stable but experiences substantial interdecadal modulations (Chowdary et al. 2012; Hu et al. 2013). In recent decades, the ENSO impact on summer climate of the NWP/EA has strengthened since the late 1970s, which is possibly caused by the increase of amplitude and periodicity of ENSO (Wang et al. 2008) and enhanced Indian Ocean capacitor effect (Xie et al. 2010a). While such interdecadal change is important for the prediction of summer climate over the NWP/EA, short observational records limit our ability to understand the underlying mechanism and project possible changes in the future. The multiple model simulations in the Coupled Model Intercomparison Project (CMIP5) are useful to explore the mechanisms for the interdecadal change and to project possible changes in the future.

Because the simulation of the relation between ENSO and August NWP/EA climate is poor in most models (not shown), we use May-July (MJJ) mean instead of June-August (JJA) mean to represent summer in this study. The poor relation between the NWP/EA August climate and ENSO in simulation is possibly because the ENSO-induced SST anomalies in the TIO are weak in August. The analysis based on JJA mean yields similar results but slightly weaker in amplitude.

This paper investigates the relationship between ENSO and NWP/EA climate in the following MJJ in CMIP5 simulations, with a focus on the change of this relationship in global warming. We show that a subset of the models feature realistic low-frequency modulations of the correlation between ENSO and the NWP/EA MJJ climate, and find that the decadal changes in the correlation in CMIP5 simulations are related to change in ENSO variability. As climate warms in response to anthropogenic forcing, the ENSO impact on NWP/EA climate in the following MJJ strengthens.

The paper is organized as follows. Section 2 provides a brief description of the models and data. Section 3 evaluates the relation between ENSO and MJJ(1) climate variance over the NWP/EA in historical runs. Here, year 1 refers to the ENSO 
decaying year. Section 4 investigates the underlying mechanism for the interdecadal change. Section 5 examines the projected change of ENSO teleconnection to NWP/EA climate in global warming. Section 6 presents the possible reasons for enhanced Indian Ocean capacitor effect in global warming. Section 7 gives a summary.

\section{Data}

Atmospheric monthly data from the NCEP Reanalysis (Kalnay et al. 1996), global SLP dataset from the Hadley Centre Sea Level Pressure dataset (HadSLP2, Allan and Ansell 2006), global precipitation data from GPCP Geostationary Satellite Precipitation Data (GPCP, Adler et al. 2003), and sea surface temperature (SST) from the Hadley Centre Sea ICE and Sea Surface Temperature dataset (HadISST, Rayner et al. 2003) are used in this study. The NCEP and HadSLP2 datasets are available on a $2.5^{\circ} \times 2.5^{\circ}$, and the HadISST data is available on a $1^{\circ} \times 1^{\circ}$ grid.

Outputs from the historical climate experiments, the representative concentration pathway 4.5 (RCP-4.5) experiments and the representative concentration pathway 8.5 (RCP-8.5) experiments from 19 CMIP5 climate models (Table 1) are analyzed and compared. More detailed online model documentations for the CMIP5 models are available at http://pcmdi3.llnl.gov/esgcet/home.htm. The historical simulations attempt to replicate climate variations during the period from 1850 to 2005 by imposing each modeling group's best estimates of natural (e.g. solar irradiance and volcanic aerosols) and anthropogenic climate forcing (e.g., greenhouse gases, sulfate aerosols, and ozone). For those models that adequately simulate the connection between ENSO and MJJ(1) climate over the NWP/EA in the historical runs, we proceed to examine the change of this relation in global warming experiments (RCP-4.5 and RCP-8.5).

Throughout this study, the analysis focuses on the impact of ENSO on NWP/EA climate on the interannual time scale. The 11-year running average has been subtracted from raw data in correlation and regression analysis to remove decadal and longer time-scale variations. For a 25-year time series, correlations of 0.34 and 0.4 reach the $90 \%$ and $95 \%$ confidence levels, respectively, based on the Student $t$ test. 


\section{Historical simulations}

We perform a singular value decomposition (SVD) analysis between MJJ(1) SLP over the NWP (Equtor- $50^{\circ} \mathrm{N}, 100^{\circ} \mathrm{E}-160^{\circ} \mathrm{E}$ ) and preceding December-February mean (DJF(0)) SST in the tropical Pacific $\left(30^{\circ} \mathrm{S}-30^{\circ} \mathrm{N}, 90^{\circ} \mathrm{E}-80^{\circ} \mathrm{W}\right)$ from 1870 to 2004 for observations and each historical simulation. Here the numerals in parentheses denote ENSO developing ( 0 ) and decay (1) years.

Figures 1 and 2 show the leading homogeneous SVD mode of SLP and SST, respectively. In observations, the leading SVD mode is characterized by high-pressure anomalies over the NWP with the maximum correlation around Philippine in MJJ(1), and El Niño-like SST anomalies in the tropical Pacific in DJF(0). The mode accounts for $84 \%$ of the total squared covariance. In most simulations, the leading SVD mode agrees well with observations, except for CanESM2, CSIRO-MK3-6-0, HadCM3 and inmem4, in which the SLP anomalies over the NWP are likely affected by local SST anomalies rather than ENSO.

Figure 3 shows the 25-year sliding correlations between the time series of the first leading SVD modes in SLP (SLP_PC1) and in SST (SST_PC1) during 1870-2004. In observations, the relation between SLP_PC1 and SST_PC1 is tight in the 1890s, the 1920s, the 1980s and the 1990s, but weak in the 1870s, the 1910s and the 1950s, confirming that the relation between ENSO and NWP/EA summer climate is unstable during 1870-2004. Most models can capture the unstable relation between the SLP_PC1 and the SST_PC1 although the timescale and phase are different from observations.

Our criteria for retaining a model for further investigation requires a degree of fidelity in simulating the ENSO-related anomalous SLP pattern over the NWP and the unstable relationship between them. Table 2 shows the spatial correlations of the first leading SLP SVD mode in each model with observations and the differences of the maximum and the minimum 25-year sliding correlations between the SLP_PC1 and SST_PC1. Eight out of nineteen models, in which the spatial correlation is above 0.65 and the difference of the maximum and the minimum sliding correlation is above 0.4 , have been chosen for further investigation. The eight models are CNRM-CM5, 
FGOALS-s2， GFDL-ESM2G， HadGEM2-CC， HadGEM2-ES， MIROC-ESM, MPI-ESM-LR and MRI-CGCM3.

Can the eight models reproduce realistic decadal change of ENSO-related climate anomalies over the NWP/EA in MJJ(1)? Figure 4 shows the differences of El Niño-related precipitation and 850-hPa wind anomalies in MJJ(1) between the highest correlation (HC) and the lowest correlation (LC) periods in observations and models. The HC and LC periods are selected based on the 25-year sliding correlations of the SLP and the SST SVD1 time series in each model. The HC period is referred to the period of 25 years with the highest correlation coefficient, whereas the LC period with the lowest correlation coefficient. Since the NCEP data only go back to 1948, we choose the 1950-1974 and 1979-2003 as LC and HC periods in the observational analysis. In observations, the difference of Niño-related $850-\mathrm{hPa}$ wind and rainfall anomalies between the $\mathrm{HC}$ and the LC periods features an anticyclone over the NWP, above-normal rainfall north of the anticyclone, and below-normal rainfall in the anticyclone. Most models are able to capture the realistic change in rainfall and $850-\mathrm{hPa}$ wind anomalies from the LC to the HC period. Although the location and structure of the NWP anticyclone anomalies in each model differ slightly from observations, the multiple-model ensemble (MME) mean resembles observations.. The results indicate that the models selected by the above criteria can capture the realistic decadal change in the relation between ENSO and NWP/EA MJJ(1) climate. Basing on the eight models, we will investigate the underlying mechanism for the decadal modulations and the possible change of the relationship between ENSO and MJJ(1) NWP/EA climate in global warming.

\section{Possible mechanism for the decadal modulations}

\section{a. Indian Ocean effect}

Figure 5 shows the evolution of MME El Niño-related SST and 850-hPa wind anomalies from November-January $\mathrm{NDJ}(0)$ to $\mathrm{MJJ}(1)$ during the $\mathrm{HC}$ and the LC periods. During NDJ(0), there are El Niño-like SST anomalies in both periods, with magnitude larger in the $\mathrm{HC}$ than the LC period, indicating that ENSO variation is higher in the HC. Corresponding to SST anomalies, there is an anomalous anticyclone 
extending from the North Indian Ocean (NIO) to the NWP at $850 \mathrm{hPa}$ in both periods, consistent with observations (Wang et al. 2000). During FMA(1), the negative SST anomalies and the anomalous anticyclone in the NWP strengthen in the HC but weaken in the LC period. Meanwhile, the warm SST anomalies in the TIO are stronger in the HC than the LC period. The intensification of TIO SST anomalies and NWP anomalous anticyclone in the HC relative to the LC period is possibly due to increase of ENSO variation. During MJJ (1), the SST anomalies in the tropical Pacific decay largely in both periods, but the TIO SST anomalies still persist and are much stronger in the HC than the LC period. According to Xie et al. (2009), the summertime TIO warming helps for the persistence of NWP anomalous anticyclone, consistent with a stronger NWP anomalous anticyclone in the HC than the LC period. The CMIP5 simulations of the Indian Ocean Capacitor effect are evaluated in Du et al. (2013).

Figure 6 contrasts the MME correlation of MJJ(1) tropospheric temperature (vertical mean from $850-\mathrm{hPa}$ to $200-\mathrm{hPa}$ ) with the DJF(0) Niño-3.4 SST index between the $\mathrm{HC}$ and the LC period. During the HC period, the El Niño-induced tropospheric temperature anomalies feature a Matsuno (1966)-Gill (1980) pattern, with a warm Kelvin wave wedge penetrating into the western Pacific along the equator and two Rossby wave-like off-equatorial tails over the western Indian Ocean. During the LC period, however, the Matsuno-Gill pattern of tropospheric temperature anomalies is not clear. In the tropics, atmospheric temperature is close to the moist adiabat determined by the temperature and the moisture content in the boundary layer, which in turn are mainly controlled by SST. Thus, the difference in tropospheric temperature distribution between two periods is mainly due to that in TIO SST anomalies. The result demonstrates that the TIO capacitor effect is stronger in the HC than the LC period with larger the ENSO-induced TIO SST anomalies triggering the Kelvin wave more easily in the HC period.

Figure 7 displays the evolution of MME precipitation correlations with $\mathrm{DJF}(0)$ Niño-3.4 SST index from NDJ(0) to MJJ(1) in the HC and the LC periods. In NDJ(0), there are positive correlations in the equatorial eastern Pacific and the western Indian 
Ocean, and negative correlations off the equatorial Pacific and the eastern Indian Ocean, with slightly larger magnitude in the HC than the LC period. In FMA(1), the TIO precipitation anomalies feature equatorial asymmetrical structure in the $\mathrm{HC}$ period, but are weak in the LC period. The springtime equatorial asymmetrical structure favor for the persistence of NIO warming by increasing solar radiation and decreasing evaporation after the southwest monsoon onset (Du et al. 2009). This explains why the NIO warming in MJJ(1) is stronger in the HC than the LC period (Fig. 5). In MJJ(1), the positive precipitation anomalies in the TIO and negative precipitation anomalies in the NWP are stronger in the HC period than the LC period, consistent with the larger SST anomalies and NWP anticyclone anomalies in the HC than the LC period (Fig. 5).

We find that all of the negative rainfall anomalies (Fig. 7), SST cooling and surface anomalous anticyclone (Fig. 5) in the NWP are stronger in the HC than the LC period from $\mathrm{NDJ}(0)$ to $\mathrm{FMA}(1)$, suggesting that the NWP air-sea interaction is stronger in the HC period from winter to spring. When it comes to MJJ(1), the NWP SST cooling becomes very weak in both periods (Fig. 5), with the minimum correlation of about -0.2 for 25 years, thus hardly contributing to the surface anticyclone. Meanwhile, the TIO warming in MJJ(1) is much stronger in the HC than the LC period, with a much stronger TIO tropospheric temperature warming that strengthens the NWP anomalous anticyclone. Thus, the interdecadal modulations of this ENSO teleconnection in early summer are likely due to the change in TIO capacitor effect in CMIP5 historical simulations. Xiang et al. (2013) reported that the local SST cooling plays an important role in enhancing NWP anomalous anticyclone in late boreal summer in observations. In CIMP5 simulations, this SST cooling effect seems not significant.

\section{b. Tropospheric temperature adjustment in AGCM}

In MJJ(1) over the TIO, the precipitation correlations with the preceding ENSO are much smaller than those of SST (Fig. 5) and tropospheric air temperature (Fig. 6). The maximum correlation in $\mathrm{MJJ}(1)$ in $\mathrm{HC}$ period is around 0.25 for TIO rainfall, above 0.5 for TIO SST and above 0.8 for TIO tropospheric temperature. The result is 
consistent with previous observational studies (Xie et al. 2009) that the relation of ENSO-TIO tropospheric temperature is tight while the relation of ENSO-TIO rainfall is weak in summer. Why is the El Niño-related air temperature warming so strong even in the absence of a strong rainfall correlation? To answer the question, we carry out two numerical experiments: AMIP and TIO, using ECHAM5 atmospheric general circulation model (AGCM) with horizontal resolution of T106 and 19 sigma levels in the vertical. A detail description of ECHAM5 is given in Roeckner et al. (2003). The AMIP experiment is forced by global observed SST from 1982 to 2011, and the TIO experiment is forced by observed SST over the TIO and climatological SST over the rest of the world ocean.

Figure 8 shows the correlation of MJJ(1) rainfall with observed DJF(0) Niño-3.4 SST index in the two experiments and observations. The pattern of rainfall anomalies in the AMIP experiment agrees well with observations (Fig. $8 \mathrm{~b}$ and 8c), with positive correlations over the western Indian Ocean and the tropical eastern Pacific and negative correlations over the tropical Atlantic, suggesting that the model can reproduce rainfall anomalies in the El Niño decaying summer. If only forced by TIO SST anomalies (Fig. 8a), the model can still reproduce the positive rainfall anomalies over the western Indian Ocean and negative rainfall anomalies over the NWP. We note that positive rainfall anomalies over the TIO are much larger in the TIO experiment (Fig. 8a) than the AMIP simulation (Fig. 8b) and observations (Fig. 8c), indicating that the TIO SST warming enhances local rainfall but SST anomalies in other regions suppress it. Thus, the relation between the TIO rainfall and $\operatorname{DJF}(0)$ Niño-3.4 SST index is weak in observations and AMIP experiment.

Although the effect of local TIO SST anomalies and the remote SST anomalies are opposite, both of them contribute to warm tropospheric temperature anomalies over the TIO. Figure 9 shows the regression of MJJ(1) tropospheric temperature on the observed DJF(0) Niño-3.4 SST index. We note that the positive tropospheric temperature anomalies over the TIO in the AMIP experiment are slightly larger than the TIO experiment, although its rainfall anomalies over the TIO are much smaller. Over the eastern Indian Ocean and the western Pacific, the tropospheric warming in 
the TIO experiment is weaker than the AMIP experiment, possibly because the negative rainfall anomalies over the Bay of Bengal and the South China Sea in TIO experiment partially offset the warm Kelvin wave. In reality, positive SST anomalies extend beyond the TIO into the South China Sea and part of NWP, helping extend the warm Kelvin wave into the western Pacific. The results demonstrate that the TIO warming in SST contributes to tropospheric warming without significant rainfall anomalies (AMIP experiment), consistent with the moist adjustment to an SST change (Chiang and Sobel 2002; Neelin and Su 2005).

\section{c. ENSO amplitude effect}

The enhancement of the TIO capacitor effect and NWP air-sea positive feedback from the $\mathrm{HC}$ to the LC period is likely linked to increasing of ENSO variation. Figure 10 compares the standard deviation of the DJF (0) Niño-3.4 SST index between two periods in each model. All models show that the amplitude of ENSO is larger in the HC than in the LC period, in agreement with observations (Wang et al. 2008).

The above results show that the modulation of ENSO influences on the NWP/EA climate in MJJ(1) is likely related to the change of the TIO capacitor effect. When the TIO capacitor effect is strong, the ENSO teleconnection to the NWP/EA summer climate is also strong. Furthermore, the change of the TIO capacitor effect is likely related to the change of ENSO amplitude, which is consistent with the observed studies (Wang et al. 2008; Chowdary et al. 2012).

\section{Projected changes in future}

This section evaluates the change in ENSO influences on the NWP/EA MJJ(1) climate in the future based on the historical, RCP-4.5 and RCP-8.5 runs. We select four periods as follows to represent different climate backgrounds: 1870-1919 in the historical run, 1950-1999 in the historical run, 2050-2099 in the RCP-4.5 run, and 2050-2099 in the RCP-8.5 run. The periods of 1870-1919 and 1951-2000 in the historical run represent the past and present climate backgrounds respectively, and the periods of 2050-2099 in the RCP-4.5 run and the RCP-8.5 run denote the future climate backgrounds with medium-low and high anthropogenic radiative forcing respectively. From 1870-1919 to 2050-2099 in the RCP-8.5 run, the global mean 
temperature and moisture increase substantially,

Figure 11 contrasts the MME tropospheric temperature and 850-hPa wind anomalies in MJJ(1) obtained by regression on the DJF(0) Niño-3.4 SST index among the four periods. In all periods, there are positive tropospheric temperature anomalies over the TIO, in agreement with observations. The tropospheric temperature anomalies over the TIO grow larger and larger from 1870-1919 to 2050-2099 in the RCP8.5 run. The tropospheric temperature anomalies are around $0.2-0.25^{\circ} \mathrm{C}$ during 1870-1919, and are above $0.3{ }^{\circ} \mathrm{C}$ during 2050-2099 in the RCP-8.5 run. With the increased tropospheric temperature anomalies, the Matsuno-Gill pattern over the TIO becomes more pronounced, and so is the warm Kelvin wave into the equatorial western Pacific. Consequently, the El Niño-related NWP anomalous anticyclone strengthens slightly from 1870-1919 to 2050-2099 in the RCP-8.5 run.

The results reveal that the El Niño-related tropospheric temperature anomalies over the TIO increase under global warming, which in turn lead to a stronger Kelvin wave over the equatorial western Pacific. In other word, the TIO capacitor effect strengthens under global warming.

\section{Mechanisms for enhanced TIO capacitor effect}

$\mathrm{Su}$ et al. (2003) demonstrated that the change of tropical tropospheric temperature is rooted in SST anomalies $\left(S S T^{\prime}\right)$. In the boundary layer, $S S T^{\prime}$ affects air temperature directly through heat exchange. In the upper levels, the tropospheric temperature change in response to $S S T^{\prime}$ is about $S S T^{\prime}+(L / C p) R H\left(d q_{s} / d T\right) S S T^{\prime}$ by moist adiabatic adjustment in the vertical, where $L$ is the latent heat of vaporization, $C p$ denotes the specific heat at constant pressure, $R H$ is relative humidity, $q_{s}$ is saturation specific humidity, $T$ is air temperature, and the value of $d q_{s} / d T$ depends on $T$. If we assume that relative humidity is constant following Held and Soden (2006), the change of tropospheric temperature would be controlled by the change of $S S T^{\prime}$ and $d q_{s} / d T$.We discuss the change of $S S T^{\prime}$ and $d q_{s} / d T$ under global warming in the following.

\section{a. The change of $S S T^{\prime}$}


Figures 12a-d show the El Niño-related MJJ(1) SST anomalies obtained by regression on the DJF(0) Niño-3.4 SST index for the four periods. Consistent with observed analyses (Xie et al. 2009), there are warm SST anomalies in the western Indian Ocean and the northern Indian Ocean in all four periods. The regional average SST anomalies over the $\mathrm{TIO}\left(20^{\circ} \mathrm{N}-20^{\circ} \mathrm{S}, 40^{\circ}-100^{\circ} \mathrm{E}\right)$ in the four periods are $0.13^{\circ} \mathrm{C}$, $0.15^{\circ} \mathrm{C}, 0.15^{\circ} \mathrm{C}$ and $0.17^{\circ} \mathrm{C}$ respectively. The MJJ(1) SST anomalies increase slightly with global warming. The possible reasons for the change of SST anomalies are discussed later.

Figure 13 shows the El Niño-related low-level air temperature anomalies (vertical average from 1000 to $850-\mathrm{hPa}$ ) for the four periods. In the tropics, the low-level air temperature anomalies and SST anomalies are similar in shape, comparable in amplitude. With global warming, the low-level air temperature anomalies increase slightly with $S S T^{\prime}$. The results indicate that the change of low-level air temperature anomalies is mainly determined by $S S T^{\prime}$.

\section{b. The change of $d q_{s} / d T$}

According to the Clausius-Clapeyron equation, $d q_{s} / d T=q_{s} L /\left(R_{v} T^{2}\right) \sim 0.06 q_{s}$, $R_{v}$ is the gas constant for water vapor, and $q_{s}$ is the saturation specific humidity. In global warming, $q_{s}$ increases so does the $d q_{s} / d T$. We calculate the regional average values of $d q_{s} / d T$ over the TIO in the four periods are $0.81,0.87,0.96$ and $1.03 \mathrm{~g} / \mathrm{Kg}^{\circ} \mathrm{C}$, respectively.

The increase of $d q_{s} / d T$ strengthens air specific humidity response to the $S S T^{\prime}$. Indeed, the El Niño-related low levels specific humidity anomalies over the TIO increases under global warming. Figure 14 shows the MJJ(1) low-level (vertical average from $1000 \mathrm{hPa}$ to $850 \mathrm{hPa}$ ) specific humidity anomalies $\left(q^{\prime}\right)$ for the four periods obtained by regression on the $\mathrm{DJF}(0)$ Niño-3.4 SST index. There are positive anomalies over the TIO, with maximum anomalies around the equator. The regional average of $q^{\prime}$ over the TIO are $0.04,0.11,0.13$ and $0.16 \mathrm{~g} / \mathrm{Kg}$ in the four periods, respectively.

$S S T^{\prime}$ also contributes to the increase of the low levels specific humidity 
anomalies over the TIO. From the periods of 1870-1919 in historical run to the period of $2050-2099$ in $\mathrm{RCP}-8.5$ run, the $\mathrm{TIO}\left(20^{\circ} \mathrm{N}-20^{\circ} \mathrm{S}, 40^{\circ}-100^{\circ} \mathrm{E}\right)$ regional average $S S T^{\prime}$ increases from 0.13 to $0.17^{\circ} \mathrm{C}$, and the $d q_{s} / d T$ increases from 0.81 to 1.03 $\mathrm{g} / \mathrm{Kg}^{\circ} \mathrm{C}$. The change of $d q_{s} / d T$ causes a $27 \%$ increase in El Niño-related low-level specific humidity anomalies over the TIO, while the change of $S S T^{\prime}$ causes an additional $31 \%$ increase in $q^{\prime}$. Both contributions are comparable.

Figure 15 shows the influence of low-level specific humidity anomalies on tropospheric temperature anomalies, the term $(L / C p) q^{\prime}$. The values of $(L / C p) q^{\prime}$ increase from 1870-1919 to 2050-2099 in the RCP-8.5 run. During 1870-1919 the values are $0.1-0.15^{\circ} \mathrm{C}$ over the $\mathrm{TIO}$, but increase to above $0.4^{\circ} \mathrm{C}$ during $2050-2099$ in RCP-8.5 run. Compared with $S S T^{\prime}$, the values of $(L / C p) q^{\prime}$ increase more quickly, indicating that the increase of El Niño-related tropospheric temperature is mainly due to the change of low-level specific humidity anomalies.

Figure 16 shows the vertical profiles of regional average air temperature anomalies over the $\mathrm{TIO}\left(20^{\circ} \mathrm{N}-20^{\circ} \mathrm{S}, 40^{\circ}-100^{\circ} \mathrm{E}\right)$ in the four periods. The air temperature anomalies increase with the height, confirming the effect of moist adiabatic adjustment. At $1000 \mathrm{hPa}$, the air temperature anomalies are $0.13,0.15,0.15$ and $0.17{ }^{\circ} \mathrm{C}$ in the four periods respectively, in agreement with SST anomalies. At 200- $\mathrm{hPa}$, the air temperature anomalies are $0.26,0.29,0.33$ and $0.38{ }^{\circ} \mathrm{C}$. From 1870-1919 to 2050-2099 in the RCP8.5 run, the low-level air temperature anomaly increases only about $0.04{ }^{\circ} \mathrm{C}$, but the upper-level air temperature anomaly increases about $0.12^{\circ} \mathrm{C}$, further confirming that the increase of El Niño-related tropospheric temperature is mainly caused by the increase of low-level specific humidity anomalies. The upper temperature anomalies over the TIO are slightly weaker than the sum of $S S T^{\prime}$ and $(L / C p) q^{\prime}$, possibly because of radiation cooling and equatorial wave dispersion from the TIO forcing region.

Changes in both $S S T^{\prime}$ and $d q_{s} / d T$ in the TIO contribute to the increase of El 
Niño-related troposphere temperature response in global warming. The increase of $d q_{s} / d T$ is directly related to global warming according to the Clausius-Clapeyron equation. But why does the TIO $S S T^{\prime}$ increase under global warming? Recently, Kosaka et al. (2013) and Wang et al. (2013) reveal a positive feedback between the NWP anomalous anticyclone and the TIO SST anomalies during summer. The NWP anomalous anticyclone strengthens the NIO warming by weakening the monsoon winds, and the NIO warming in turn helps sustain the NWP anomalous anticyclone. Under global warming (Fig. 11), increased TIO $S S T^{\prime}$ and surface humidity strengthen tropospheric temperature anomalies and NWP anomalous anticyclone than in the present, and the enhanced NWP anomalous anticyclone in turn leads to increased TIO $S S T^{\prime}$, suggesting the positive feedback strengthens, consistent with Tao et al. (2014). Indeed, we find that both TIO $S S T^{\prime}$ and the NWP anomalous anticyclone strengthen from 1870-1919 to 2050-2099 in RCP8.5 run (Fig. 11). Some studies (Xie et al. 2010b, Zheng et al. 2013), however, suggest that the springtime thermocline depth in the southwest TIO will increase under global warming, which is not favorable for the persistent of TIO warming in El Niño decay phase (Xie et al. 2010a). The change of the springtime thermocline depth in the southwest TIO may counteract the effect of the increase of $d q_{s} / d T$ to some extent; so the increase of El Niño-related $S S T^{\prime}$ over the TIO is modest.

We also examine the change of ENSO variability under global warming. Figure 17 shows DJF Niño-3.4 SST index standard deviation in four periods. The trends of ENSO variance in global warming vary among different models. In some models such as MPI-ESM-LR and FGOALS-s2, the ENSO variance increases, and in some other models such as HadGEM2-ES, the ENSO variance decreases. In MME, the difference in ENSO variance among the four periods is very small. So it is not yet possible to say whether ENSO activity will enhance or decrease, consistent with Collins et al. (2010). Unlike the decadal modulation, the TIO capacitor effect strengthens under global warming is less related to the change of ENSO activity.

\section{Summary}

The outputs of CMIP5 simulations have been used to examine the ENSO impact 
on MJJ(1) climate in the NWP/EA. In the historical run, 8 out of 19 models capture not only the realistic El Niño-related anomalies over the subtropical NWP but also the interdecadal modulations of this ENSO teleconnection. We have examined the role of the NWP local air-sea interaction and the TIO capacitor effect in this interdecadal modulation. We find that the NWP air-sea interaction is stronger in the HC than the LC period from winter to spring. When it comes to MJJ(1), the NWP SST cooling becomes too weak to contribute to the surface anticyclone. Meanwhile, the significant TIO SST warming is much stronger in the HC than the LC period, with a much stronger TIO tropospheric temperature warming that strengthens the NWP anomalous anticyclone. Thus, the interdecadal modulations of this ENSO teleconnection in early summer are likely due to the change in TIO capacitor effect in CMIP5 historical simulations. ENSO amplitude appears to modulate the magnitude of the TIO capacitor effect. The low frequency modulation of ENSO amplitude and the TIO capacitor effect also exists in RCP-4.5 run and RCP8.5-run (not shown).

Under global warming, the ENSO impact on tropospheric temperature and NWP/EA MJJ(1) climate strengthens, a result consistent with the study of Zheng et al. (2011) based on a single model. According to the Clausius-Clapeyron equation, the specific humidity response to interannual SST variability strengthens in a warmer climate. Thus, the El Niño-induced TIO warming would lead to larger humidity anomalies than in the present, leading to a larger TIO troposphere warming and warm Kelvin wave, even with the same amplitude of TIO SST anomalies. Unlike the natural modulation, the ENSO impact on NWP/EA MJJ(1) climate strengthens under global warming independent of how ENSO might change in the future. Model projections of ENSO amplitude change are uncertain (Collins et al. 2010), because of large nature modulations, although tree-ring-based ENSP reconstruction suggests an increase of ENSO amplitude in recent decades above the background level (Li et al. 2013)..

\section{Acknowledgements}

We acknowledge the World Climate Research Program's Working Group on Coupled Modeling, which is responsible for CMIP, and we thank the climate modeling groups listed in Table 1 for producing and making available their model 
output. For CMIP the U.S. Department of Energy's Program for Climate Model Diagnosis and Intercomparison provides coordinating support and led development of software infrastructure in partnership with the Global Organization for Earth System Science Portals". We wish to thank three anonymous reviewers for their useful comments. The study is supported by the National Basic Research Program of China (2012CB955604, 2011CB309704), NSFC (41275083, 41275081, 41106010 and 41205050), and the U.S. NSF. 


\section{Reference}

Adler, R.F., G.J. Huffman, A. Chang, R. Ferraro, P. Xie, J. Janowiak, B. Rudolf, U. Schneider, S. Curtis, D. Bolvin, A. Gruber, J. Susskind, and P. Arkin, 2003: The Version 2 Global Precipitation Climatology Project (GPCP) Monthly Precipitation Analysis (1979-Present). J. Hydrometeor, 4,1147-1167.

Allan, Rob, Tara Ansell, 2006: A New Globally Complete Monthly Historical Gridded Mean Sea Level Pressure Dataset (HadSLP2): 1850-2004. J. Climate, 19, 5816-5842.

Chang, C. P., Y. S. Zhang, and T. Li, 2000: Interannual and interdecadal variations of the East Asian summer monsoon and tropical Pacific SSTs. Part I: Roles of the subtropical ridge. J. Climate, 13, 4310-4325.

Chiang, J. C., and A. H. Sobel, 2002: Tropical Tropospheric Temperature Variations Caused by ENSO and Their Influence on the Remote Tropical Climate. $J$. Climate, 15, 2616-2631.

Chowdary, J. S., S. P. Xie, H. Tokinaga, Y. M. Okumura, H. Kubota, N. Johnson, and X. T. Zheng, 2012: Interdecadal Variations in ENSO Teleconnection to the Indo-Western Pacific for 1870-2007. J. Climate, 25, 1722-1744.

Collins, M., and Coauthors, 2010: The impact of global warming on the tropical Pacific Ocean and El Niño. Nature Geoscience, 3, 391-397.

Du, Y., S.-P. Xie, G. Huang, and K. Hu, 2009: Role of Air-Sea Interaction in the Long Persistence of El Niño-Induced North Indian Ocean Warming. J. Climate, 22, 2023-2038.

Du, Y., S.-P. Xie, Y.-L. Yang, X.-T. Zheng, L. Liu, and G. Huang 2013: Indian Ocean variability in the CMIP5 multi-model ensemble: The basin mode. $J$. Climate, 26, 7240-7266.

Gill, A. E., 1980: Some simple solutions for heat-induced tropical cirulation. Quart. J. Roy. Meteor. Soc., 106, 447-462.

Held, I. M., and B. J. Soden, 2006: Robust responses of the hydrological cycle to global warming. J. Climate, 19, 5686-5699.

Hu, K., G. Huang, and R. Huang, 2011: The Impact of Tropical Indian Ocean 
Variability on Summer Surface Air Temperature in China. J. Climate, 24, 5365-5377.

Hu, K. M., Gang Huang, Xia Qu, and R. Huang, 2012: The Impact of Indian Ocean variability on high temperature extremes across south of Yangtze River Valley in late summer. Adv. Atmos. Sci., 29, 91-100.

Hu, K., G. Huang, and R. Wu, 2013: A Strengthened Influence of ENSO on August High Temperature Extremes over the Southern Yangtze River Valley since the Late 1980s. J. Climate, 26, 2205-2221.

Huang, G., K. Hu, and S.-P. Xie, 2010: Strengthening of Tropical Indian Ocean Teleconnection to the Northwest Pacific since the Mid-1970s: An Atmospheric GCM Study. J. Climate, 23, 5294-5304.

Huang, R., and Y. Wu, 1989: The influence of ENSO on the summer climate change in China and its mechanism. Adv. Atmos. Sci., 6, 21-32.

Kalnay, E., and Coauthors, 1996: The NCEP/NCAR 40-year reanalysis project. Bull. Amer. Meteor. Soc., 77, 437-471.

Kosaka, Y., S.-P. Xie, N.-C. Lau, and G. Vecchi, 2013: Origin of seasonal predictability for summer climate over the Northwestern Pacific. PNAS, 110, 7574-7579, doi: 10.1073/pnas.1215582110.

Lau, N.-C., and M. J. Nath, 2009: A Model Investigation of the Role of Air-Sea Interaction in the Climatological Evolution and ENSO-Related Variability of the Summer Monsoon over the South China Sea and Western North Pacific. J. Climate, 22, 4771-4792.

Li, J., S.-P. Xie, E. Cook, M. Morales, D. Christie, N. Johnson, F. Chen, R. D'Arrigo, A. Fowler, X. Gou, and K. Fang, 2013: El Nino modulations over the past seven centuries. Nature Clim. Change, 3, 822-826

Matsuno, T., 1966: Quasi-geostrophic motions in the equatorial area. J. Meteor. Soc. Japan., 44, 25-43.

Neelin, J. D., and H. Su, 2005: Moist Teleconnection Mechanisms for the Tropical South American and Atlantic Sector. J. Climate, 18, 3928-3950.

Nitta, T., 1987: Convective activities in the tropical western Pacific and their impact 
on the Northern Hemisphere summer circulation. J. Meteor. Soc. Japan., 65, 373-390.

Rayner, N. A., and Coauthors, 2003: Global analyses of sea surface temperature, sea ice, and night marine air temperature since the late nineteenth century. $J$. Geophys. Res., 108, 4407, doi:4410.1029/2002JD002670.

Su, H., J. D. Neelin, and J. E. Meyerson, 2003: Sensitivity of Tropical Tropospheric Temperature to Sea Surface Temperature Forcing. J. Climate, 16, 1283-1301.

Tao, W., G. Huang, K. Hu, X. Qu, G. Wen, and H. Gong, 2014: Interdecadal modulation of ENSO teleconnections to the Indian Ocean Basin Mode and their relationship under global warming in CMIP5 models. Int. J. Climatol, doi: 10.1002/joc.3987, (in press).

Wang, B., R. G. Wu, and X. H. Fu, 2000: Pacific-East Asian teleconnection: how does ENSO affect East Asian climate? J. Climate, 13, 1517-1536.

Wang, B., R. G. Wu, and T. Li, 2003: Atmosphere-warm ocean interaction and its impacts on Asian-Australian monsoon variation. J. Climate, 16, 1195-1211.

Wang, B., B. Xiang, and J.-Y. Lee, 2013: Subtropical High predictability establishes a promising way for monsoon and tropical storm predictions. PNAS,110, 2718-2722, doi:10.1073/pnas.1214626110.

Wang, B., J. Yang, and T. J. Zhou, 2008: Interdecadal changes in the major modes of Asian-Australian monsoon variability: Strengthening relationship with ENSO since the late 1970s. J. Climate, 21, 1771-1789.

Wu, B., T. Li, and T. Zhou, 2010: Relative Contributions of the Indian Ocean and Local SST Anomalies to the Maintenance of the Western North Pacific Anomalous Anticyclone during the El Niño Decaying Summer.. J. Climate, 23, 2974-2986.

Wu, R., Z. Z. Hu, and B. P. Kirtman, 2003: Evolution of ENSO-related rainfall anomalies in East Asia. J. Climate, 16, 3742-3758.

Xiang, B., B. Wang, W. Yu, and S. Xu, 2013: How can anomalous western North Pacific Subtropical High intensify in late summer? Geophys. Res. Lett., 40, 2349-2354, doi:10.1002/grl.50431. 
Xie, S. P., K. M. Hu, J. Hafner, H. Tokinaga, Y. Du, G. Huang, and T. Sampe, 2009: Indian Ocean Capacitor Effect on Indo-Western Pacific Climate during the Summer following E1 Niño. J. Climate, 22, 730-747.

Xie, S. P., Y. Du, G. Huang, X. T. Zheng, H. Tokinaga, K. Hu, and Q. Liu, 2010a: Decadal Shift in El Ni o Influences on Indo--Western Pacific and East Asian Climate in the 1970s. J. Climate, 23, 3352-3368.

Xie, S. P., C. Deser, G. A. Vecchi, J. Ma, H. Teng, and A. T. Wittenberg, 2010b: Global Warming Pattern Formation: Sea Surface Temperature and Rainfall. $J$. Climate, 23, 966-986.

Zhang, R., A. Sumi, and M. Kimoto, 1996: Impact of El Niño on the East Asian monsoon : A diagnostic study of the '86/87 and '91/92 events. J. Meteor. Soc. Japan., 74, 49-62.

Zheng, X. T., S. P. Xie, and Q. Liu, 2011: Response of the Indian Ocean Basin Mode and Its Capacitor Effect to Global Warming. J. Climate, 24, 6146-6164.

Zheng, X.-T., S.-P. Xie, Y. Du, L. Liu, G. Huang, and Q. Liu, 2013: Indian Ocean Dipole Response to Global Warming in the CMIP5 Multimodel Ensemble. $J$ Climate, 26, 6067-6080. 
Table 1. Climate models and corresponding atmospheric resolution.

\begin{tabular}{ll}
\hline Model ID & $\begin{array}{l}\text { Atmospheric GCM } \\
\text { Resolution }\end{array}$ \\
\hline CanESM2 & T42 $\left(\sim 2.8125^{\circ} \times 2.8125^{\circ}\right)$ \\
CCSM4 & $0.9^{\circ} \times 1.25^{\circ}$ \\
CNRM-CM5 & T85 $\left(\sim 1.40625^{\circ} \times 1.40625^{\circ}\right)$ \\
CSIRO-Mk3-6-0 & $\sim 1.9^{\circ} \times 1.9^{\circ}$ \\
FGOALS-s2 & $\mathrm{R} 42\left(\sim 1.66^{\circ} \times 2.81^{\circ}\right)$ \\
GFDL-CM3 & $\mathrm{C} 48\left(2^{\circ} \times 2.5^{\circ}\right)$ \\
GFDL-ESM2G & $2^{\circ} \times 2.5^{\circ}$ \\
GISS-E2-H & $2^{\circ} \times 2.5^{\circ}$ \\
HadCM3 & $\mathrm{N} 48\left(\sim 2.47^{\circ} \times 3.75^{\circ}\right)$ \\
HadGEM2-CC & $1.875^{\circ} \times 1.25^{\circ}$ \\
HadGEM2-ES & $1.875^{\circ} \times 1.25^{\circ}$ \\
Inmcm4 & $2^{\circ} \times 1.5^{\circ}$ \\
IPSL-CM5A-LR & $1.875^{\circ} \times 3.75^{\circ}$ \\
MIROC5 & $\mathrm{T} 85\left(\sim 1.40625^{\circ} \times 1.40625^{\circ}\right)$ \\
MIROC-ESM & $\mathrm{T} 42\left(\sim 2.8125^{\circ} \times 2.8125^{\circ}\right)$ \\
MIROC-ESM-CHEM & $\mathrm{T} 42\left(\sim 2.8125^{\circ} \times 2.8125^{\circ}\right)$ \\
MPI-ESM-LR & $\mathrm{T} 63\left(\sim 1.875^{\circ} \times 1.875^{\circ}\right)$ \\
MRI-CGCM3 & $\mathrm{T} 85\left(\sim 1.40625^{\circ} \times 1.40625^{\circ}\right)$ \\
NorESM1-M & $1.9^{\circ} \times 2.5^{\circ}$ \\
\hline
\end{tabular}

Table 2. Spatial correlations with observations and the difference of the maximum and the minimum 25-year sliding correlation coefficients.

\begin{tabular}{llllll}
\hline ID & $\begin{array}{l}\text { Spatial } \\
\text { correlation }\end{array}$ & Max-Min & ID & $\begin{array}{l}\text { Spatial } \\
\text { correlation }\end{array}$ & Max-Min \\
\hline OBS. & 1 & 0.56 & HadGEM2-CC & 0.84 & 0.50 \\
CanESM2 & -0.63 & 0.73 & HadGEM2-ES & 0.76 & 0.70 \\
CCSM4 & 0.64 & 0.26 & Inmcm4 & -0.30 & 0.30 \\
CNRM-CM5 & 0.79 & 0.41 & IPSL-CM5A-LR & 0.50 & 0.53 \\
CSIRO-Mk3-6-0 & -0.18 & 0.36 & MIROC5 & 0.65 & 0.32 \\
FGOALS-s2 & 0.65 & 0.52 & MIROC-ESM & 0.66 & 0.69 \\
GFDL-CM3 & 0.66 & 0.35 & MIROC-ESM-CHEM & 0.44 & 0.79 \\
GFDL-ESM2G & 0.72 & 0.82 & MPI-ESM-LR & 0.66 & 0.58 \\
GISS-E2-H & 0.59 & 0.74 & MRI-CGCM3 & 0.66 & 0.58 \\
HadCM3 & -0.79 & 0.62 & NorESM1-M & 0.61 & 0.52 \\
\hline
\end{tabular}




\section{Figure Captions}

Fig. 1. The homogeneous correlation maps of the first SVD mode (contours; shade denote 95\% confidence level) of MJJ(1) SLP over the Northwest Pacific in observation and 19 models runs from CMIP5 historical experiment. The SVD analysis is based on the period from 1870 to 2004 .

Fig. 2. The homogeneous correlation maps of the first SVD mode (contours; shade denote $95 \%$ confidence level) of DJF (0) SST in the tropical Pacific in observation and 19 models runs from CMIP5 historical experiment. The SVD analysis is based on the period from 1870 to 2004 .

Fig. 3. The 25-year sliding correlation between SLP_PC1 (the time series of the first leading SLP SVD mode) and SST_PC1 (the time series of the first leading SST SVD mode) in observation and 19 models from CMIP5 historical experiment. The dashed lines denote the $95 \%$ confidence level.

Fig. 4. The difference of MJJ(1) precipitation (colors; mm/month) and 850-hPa wind anomalies (vectors) obtained by regression on the normalized DJF(0) Niño-3.4 SST index between the HC and the LC periods in observation and 8 selected models from CMIP5 historical experiment. The MME denotes the Multi-Model ensemble of the eight model results.

Fig. 5. The MME correlation of SST (colors) and regression of $850-\mathrm{hPa}$ winds with the DJF (0) Niño-3.4 SST index from NDJ (0) to MJJ(1) during the LC (left) and the $\mathrm{HC}$ (right) periods in the historical run.

Fig. 6. The MME correlation of MJJ(1) tropospheric temperature (vertical average from 850 to $200-\mathrm{hPa}$ ) with the DJF (0) Niño-3.4 SST index in the LC (a) and the HC (b) periods.

Fig. 7. The MME correlation of precipitation (colors) with the DJF (0) Niño-3.4 SST index from NDJ (0) to MJJ (1) during the LC (left) and the HC (right) periods in the historical run.

Fig. 8. Correlation of MJJ(1) precipitation with observed DJF(0) Niño-3.4 SST index in the TIO experiment (a), the AMIP experiment (b) and the observation (c). 
Fig. 9. Regression of $\mathrm{MJJ}(1)$ tropospheric temperature (vertical average from $850 \mathrm{hPa}$ to $200 \mathrm{hPa}$, unit: $\mathrm{k}$ ) on normalized observational DJF(0) Niño-3.4 SST index in the TIO experiment (a) and the AMIP experiment (b).

Fig. 10. Standard deviation of the DJF Niño-3.4 SST index in the LC (blue) and HC (red) periods.

Fig. 11. Multi-Model ensemble mean of MJJ(1) tropospheric temperature anomalies (colors; vertical average from 850 to $200-\mathrm{hPa}$; unit ${ }^{\circ} \mathrm{C}$ ) and $850-\mathrm{hPa}$ winds anomalies (vectors; units m/s) obtained by regression on normalized DJF (0) Niño-3.4 SST index during the period of 1870-1919 in the historical run (a), 1951-2000 in the historical run (b), 2050-2099 in the RCP-4.5 run (c), and 2050-2099 in the RCP-8.5 $\operatorname{run}(d)$.

Fig. 12. Multi-Model ensemble mean of MJJ(1) SST anomalies (colors; unit ${ }^{\circ} \mathrm{C}$ ) obtained by regression on normalized DJF (0) Niño-3.4 SST index during the period of 1870-1919 in the historical run (a), 1951-2000 in the historical run (b), 2050-2099 in the RCP-4.5 run (c), and 2050-2099 in the RCP-8.5 run (d).

Fig. 13. Multi-Model ensemble mean of MJJ(1) low-level air temperature anomalies (vertical average from 1000 to $850-\mathrm{hPa}$; unit ${ }^{\circ} \mathrm{C}$ ) obtained by regression on normalized DJF (0) Niño-3.4 SST index during the period of 1870-1919 in the historical run (a), 1951-2000 in the historical run (b), 2050-2099 in the RCP-4.5 run (c), and 2050-2099 in the RCP-8.5 run (d).

Fig. 14. Multi-Model ensemble mean of low-level specific humidity anomalies (vertical average from 1000 to $850-\mathrm{hPa}$; units $\mathrm{g} / \mathrm{Kg}$ ) obtained by regression on normalized DJF (0) Niño-3.4 SST index during the period of 1870-1919 in the historical run (a), 1951-2000 in the historical run (b), 2050-2099 in the RCP-4.5 run (c), and 2050-2099 in the RCP-8.5 run (d).

Fig. 15. Multi-Model ensemble mean of the term of $(L / C p) q^{\prime}$, where $L$ is the latent heat of vaporization, $C p$ denotes the specific heat at constant pressure and $q^{\prime}$ is the MJJ(1) low-level (vertical average from 1000 to $850-\mathrm{hPa}$ ) specific humidity anomaly obtained by regression on normalized DJF (0) Niño-3.4 SST index during the period 
of 1870-1919 in the historical run (a), 1951-2000 in the historical run (b), 2050-2099 in the RCP-4.5 run (c), and 2050-2099 in the RCP-8.5 run (d).

Fig. 16. Multi-Model ensemble mean of MJJ(1) area mean temperature anomalies profile over the $\mathrm{TIO}\left(20^{\circ} \mathrm{S}-20^{\circ} \mathrm{N}, 40^{\circ} \mathrm{E}-100^{\circ} \mathrm{E}\right)$ obtained by regression on normalized DJF (0) Niño-3.4 SST index during the period of 1870-1919 in the historical run (black), 1951-2000 in the historical run (red), 2050-2099 in the RCP-4.5 run (blue) and 2050-2099 in the RCP-8.5 run (yellow).

Fig.17. Standard deviation of the DJF Niño-3.4 SST index during the period of 1870-1919 in the historical run (blue), 1951-2000 in the historical run (yellow), 2050-2099 in the RCP-4.5 run (green) and 2050-2099 in the RCP-8.5 run (red). 

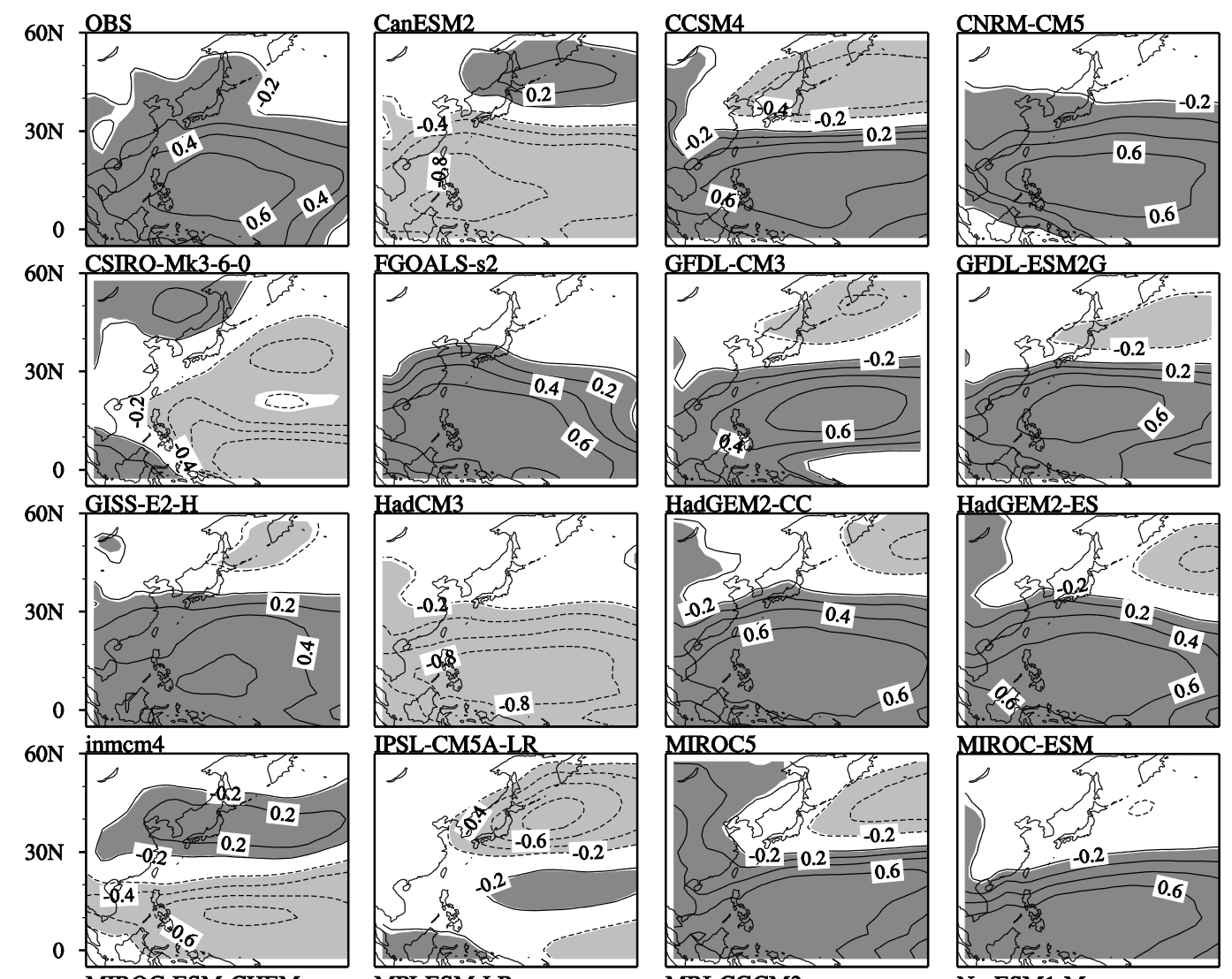

FGOALS-s2

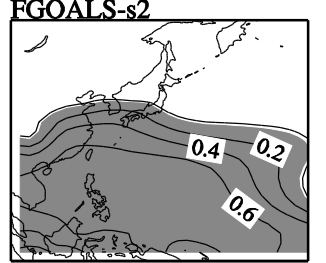

GFDL-CM3

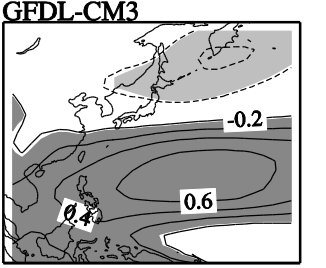

HadCM3
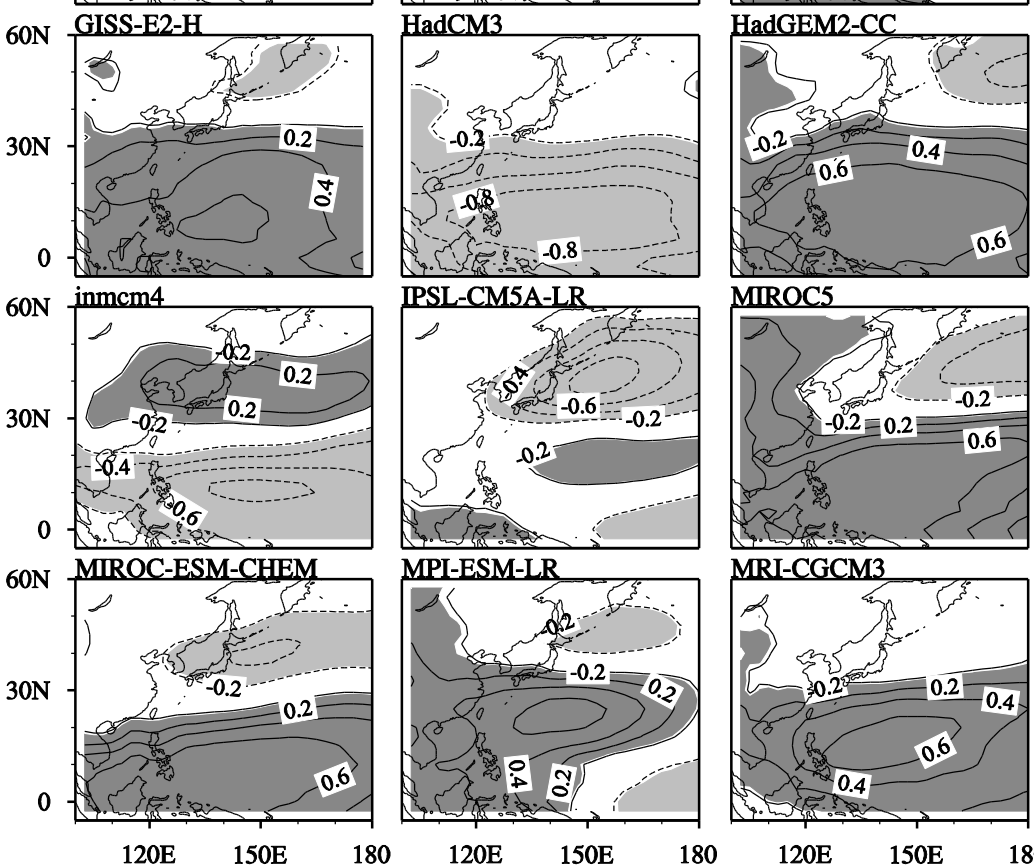

MPI-ESM-LR
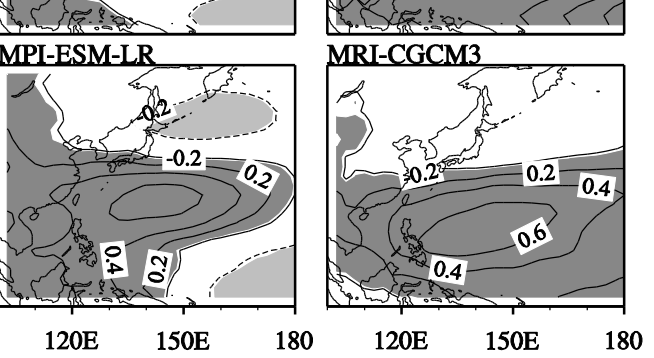

GFDL-ESM2G
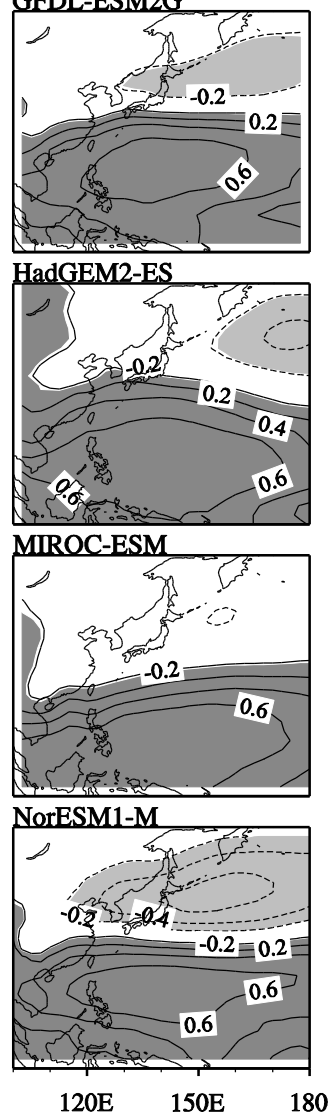

Fig. 1. The homogeneous correlation maps of the first SVD mode (contours; shade denote 95\% confidence level) of MJJ(1) SLP over the Northwest Pacific in observation and 19 models runs from CMIP5 historical experiment. The SVD analysis is based on the period from 1870 to 2004 . 

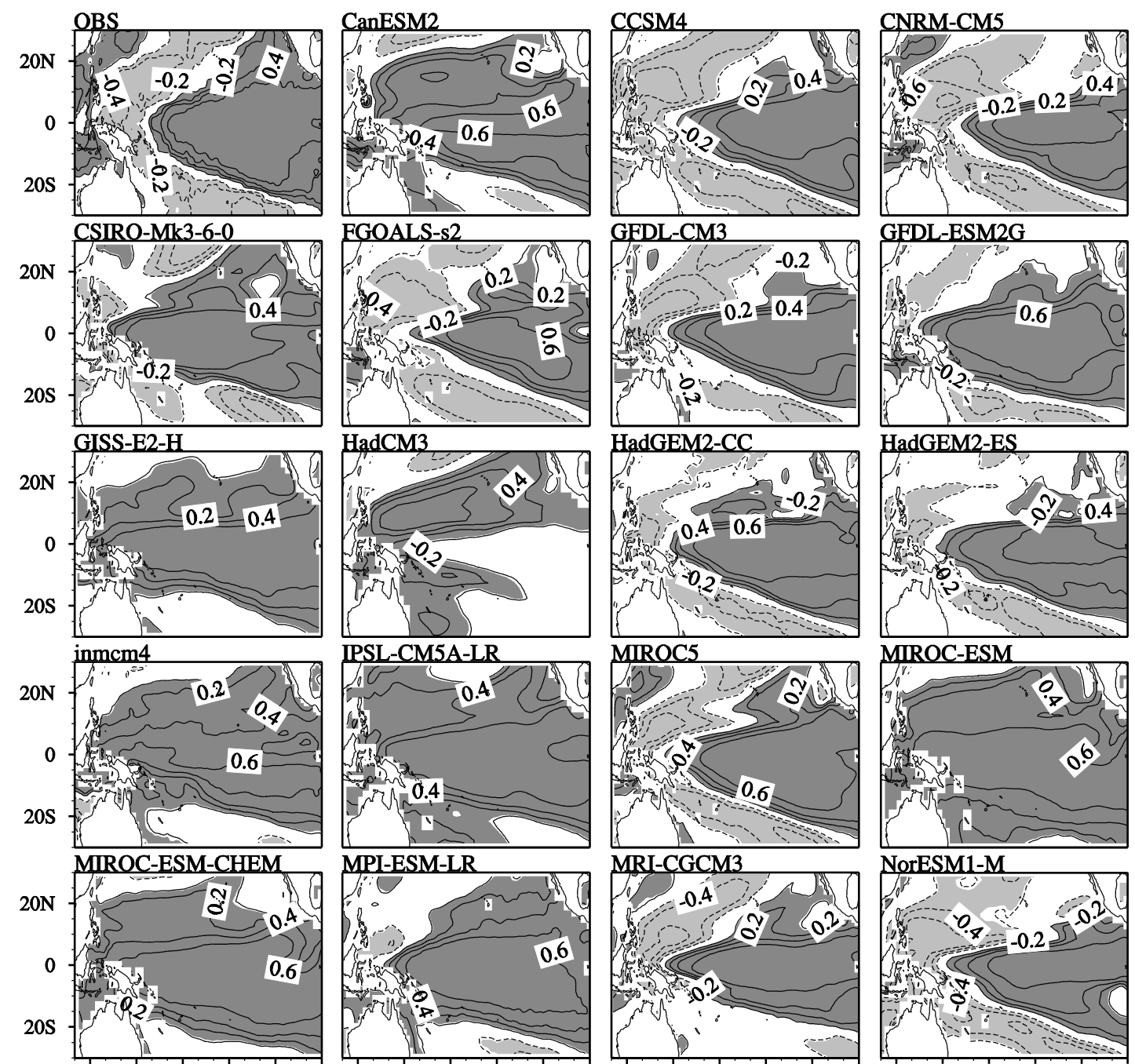

120E 150E 180 150W120W 90W120E 150E 180 150W120W 90W120E 150E 180 150W120W 90W120E 150E 180 150W120W 90W

Fig. 2. The homogeneous correlation maps of the first SVD mode (contours; shade denote 95\% confidence level) of DJF (0) SST in the tropical Pacific in observation and 19 models runs from CMIP5 historical experiment. The SVD analysis is based on the period from 1870 to 2004 . 

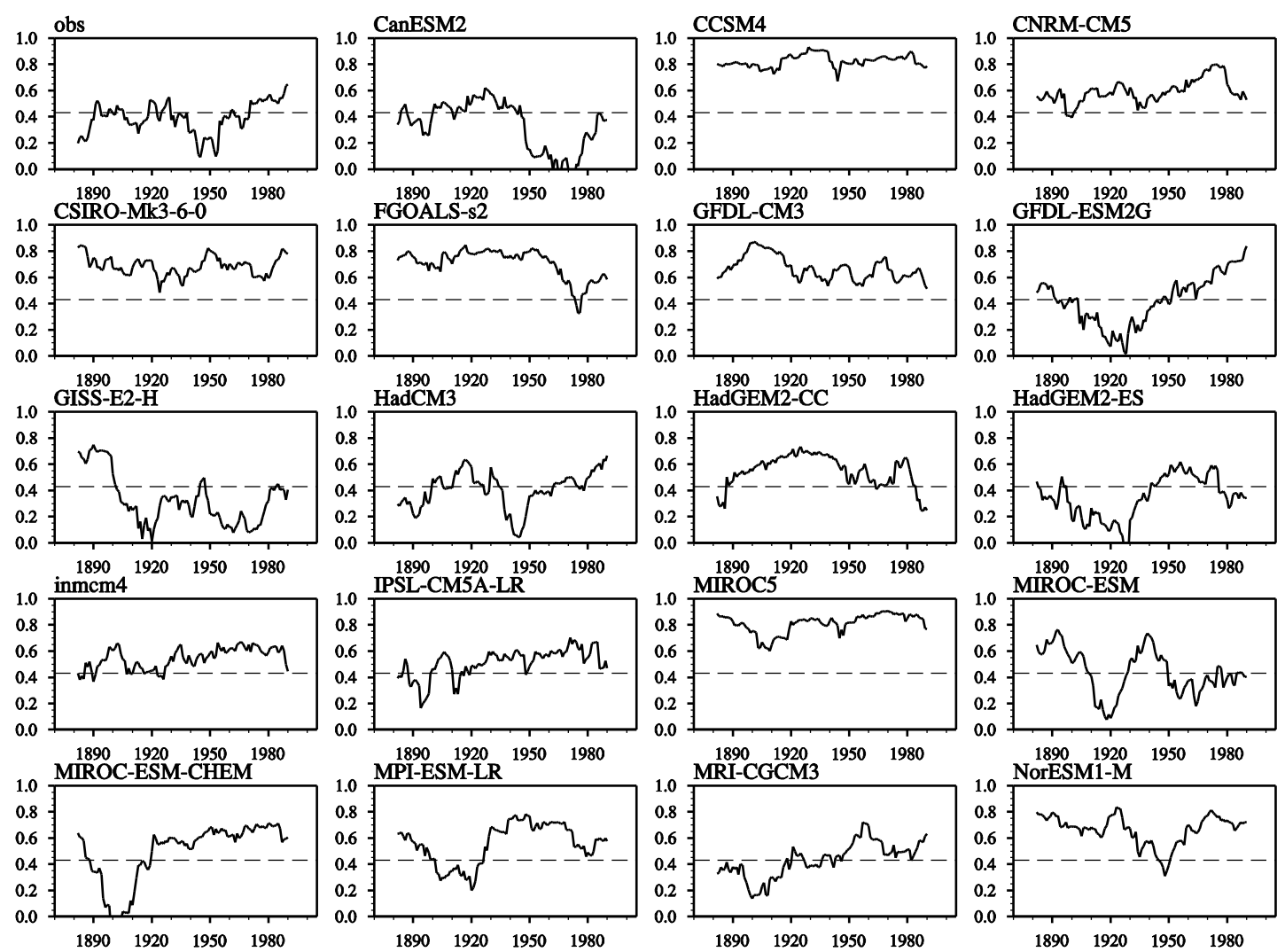

Fig. 3. The 25-year sliding correlation between SLP_PC1 (the time series of the first leading SLP SVD mode) and SST_PC1 (the time series of the first leading SST SVD mode) in observation and 19 models from CMIP5 historical experiment. The dashed lines denote the $95 \%$ confidence level. 


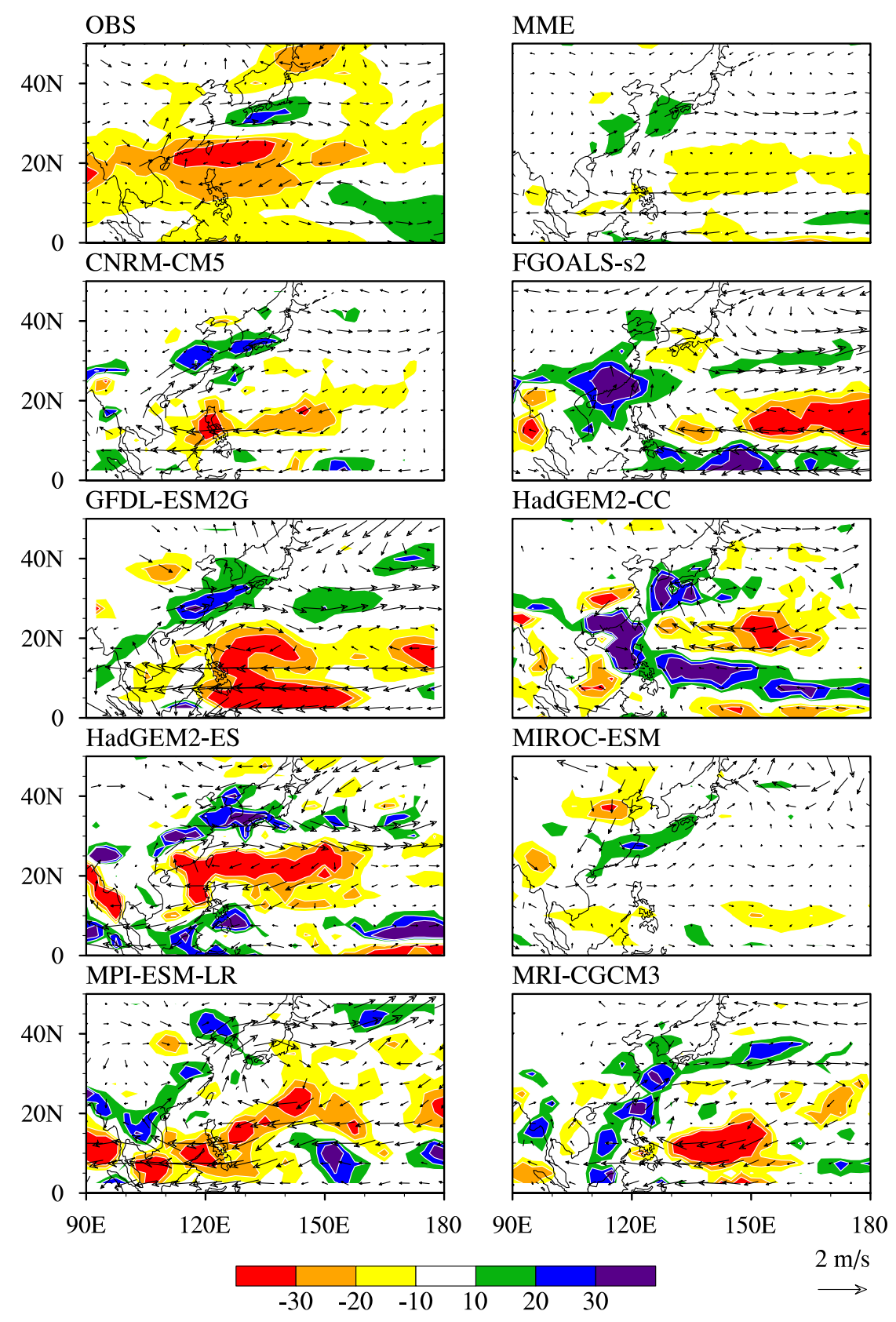

Fig. 4. The difference of MJJ(1) precipitation (colors; mm/month) and 850-hPa wind anomalies (vectors) obtained by regression on the normalized DJF(0) Niño-3.4 SST index between the HC and the LC periods in observation and 8 selected models from CMIP5 historical experiment. The MME denotes the Multi-Model ensemble of the eight model results. 

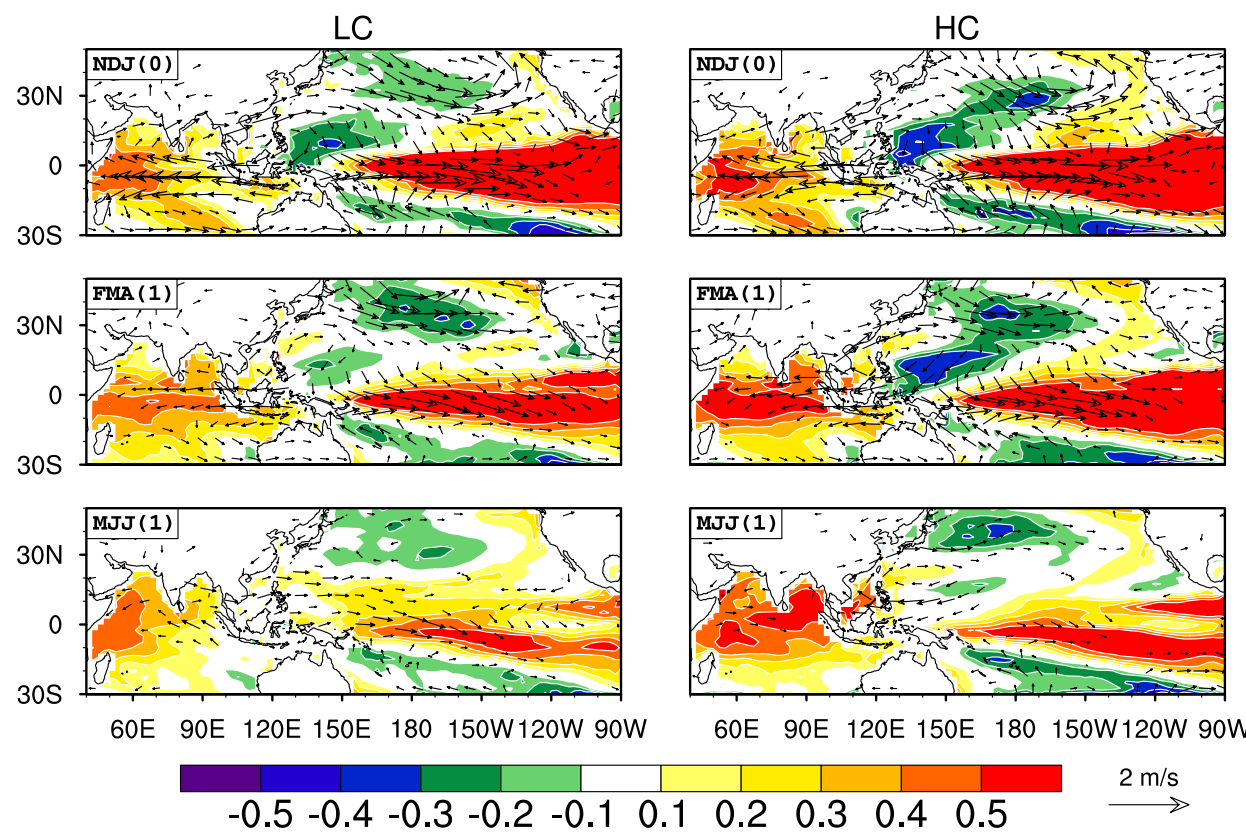

Fig. 5. The MME correlation of SST (colors) and regression of $850-\mathrm{hPa}$ winds with the DJF (0) Niño-3.4 SST index from NDJ (0) to MJJ(1) during the LC (left) and the $\mathrm{HC}$ (right) periods in the historical run. 
(a) LC
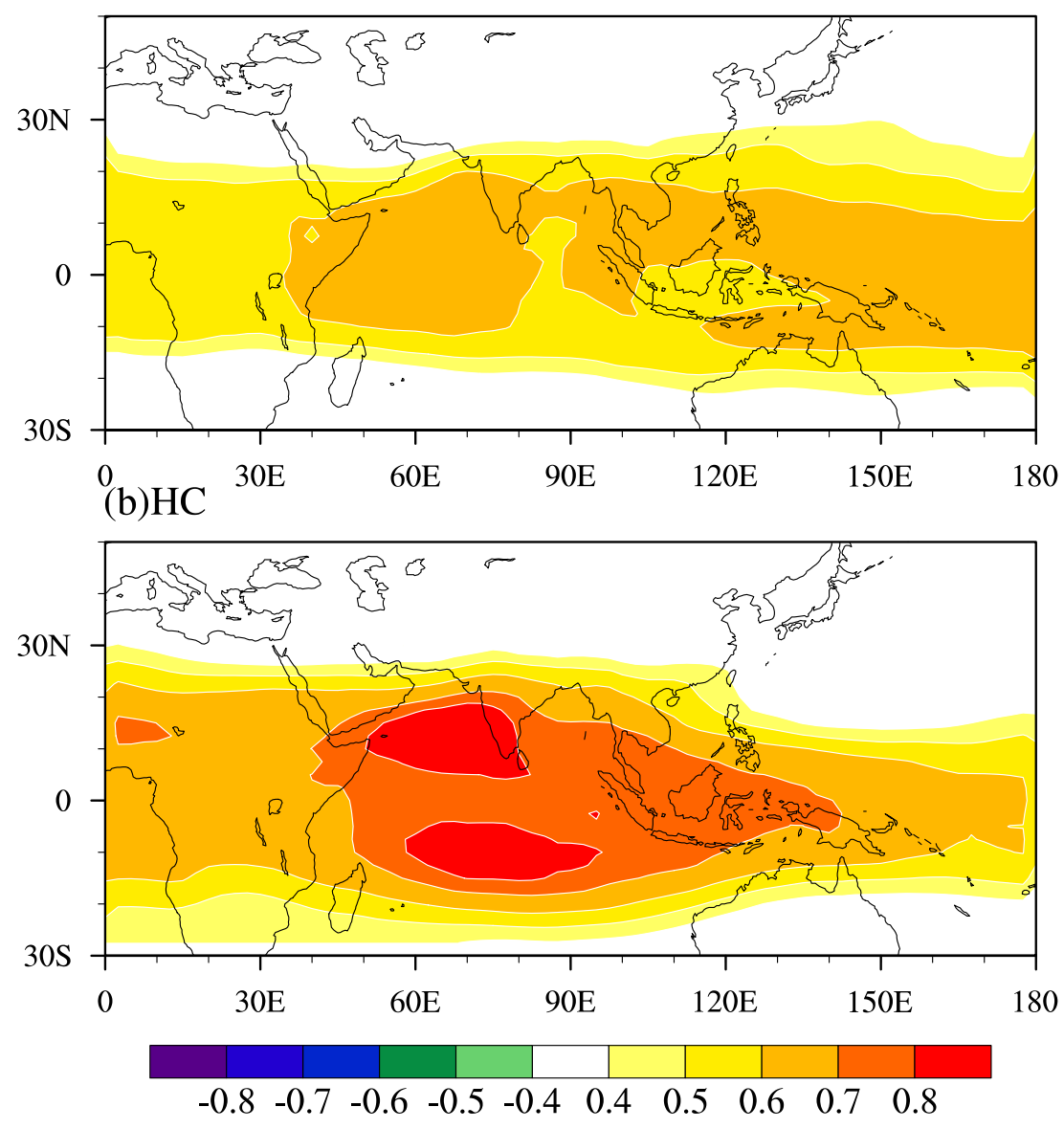

Fig. 6. The MME correlation of MJJ(1) tropospheric temperature (vertical average from 850 to $200-\mathrm{hPa}$ ) with the DJF (0) Niño-3.4 SST index in the LC (a) and the HC (b) periods. 

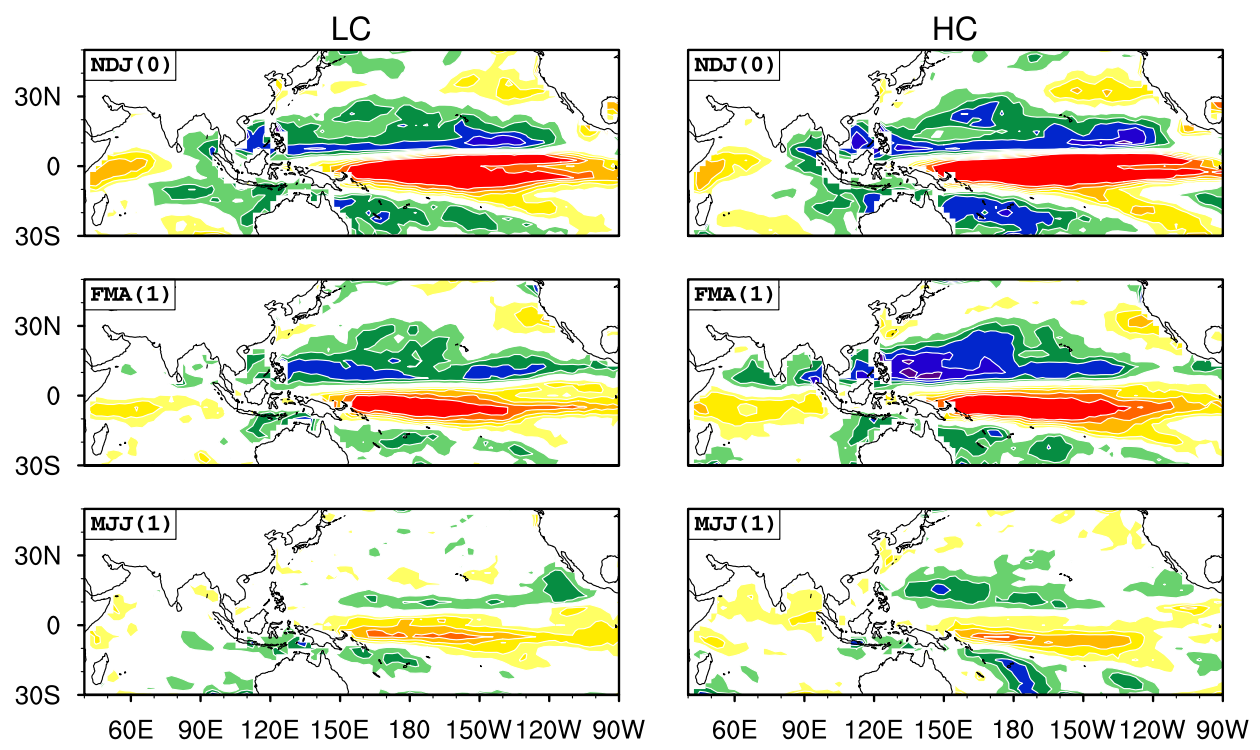

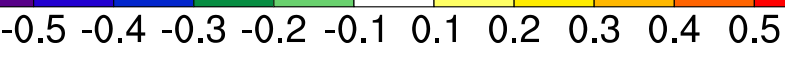

Fig. 7. The MME correlation of precipitation (colors) with the DJF (0) Niño-3.4 SST index from NDJ (0) to MJJ (1) during the LC (left) and the HC (right) periods in the historical run. 
(a) $\mathrm{TIO}$
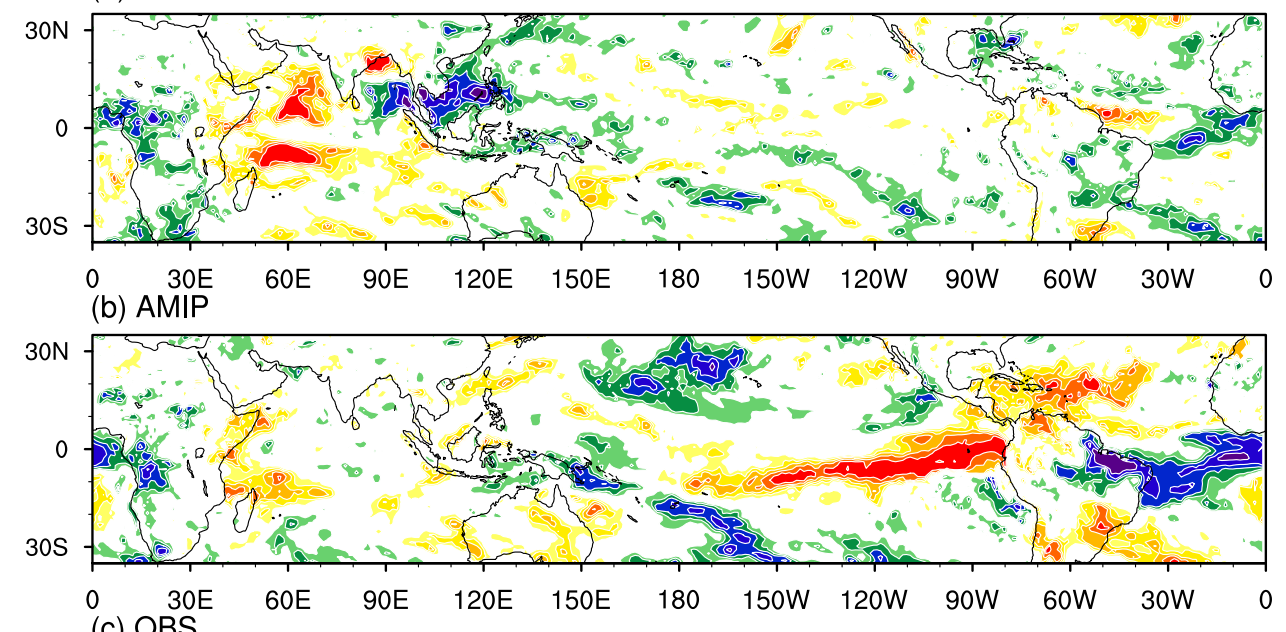
(c) OBS

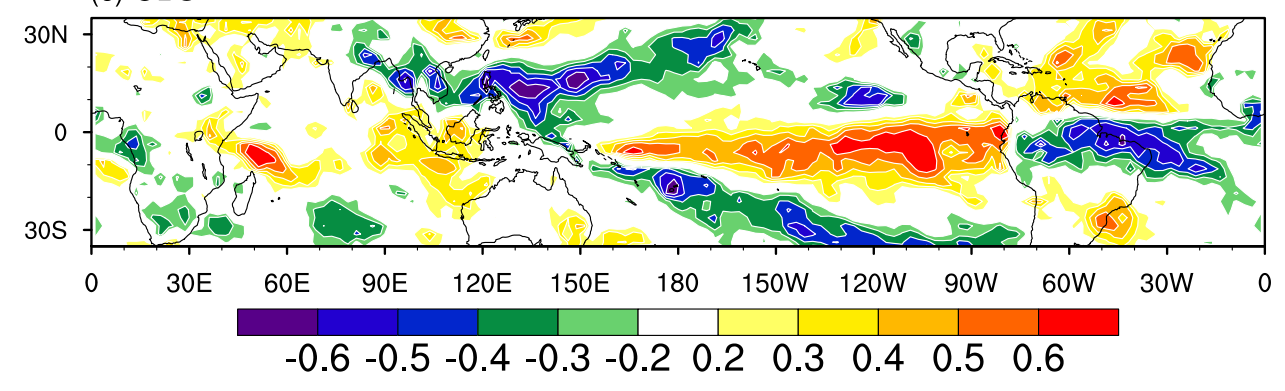

Fig. 8. Correlation of MJJ(1) precipitation with observed DJF(0) Niño-3.4 SST index in the TIO experiment (a), the AMIP experiment (b) and the observation (c). 
(a) $\mathrm{TIO}$

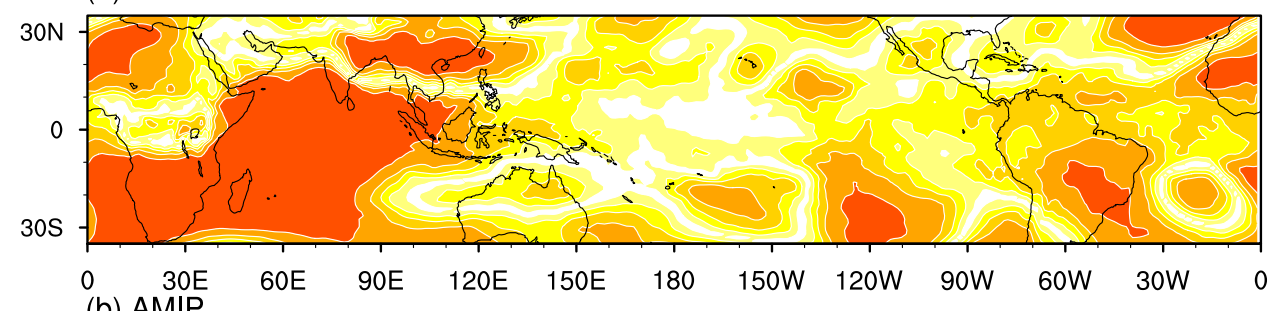
(b) AMIP

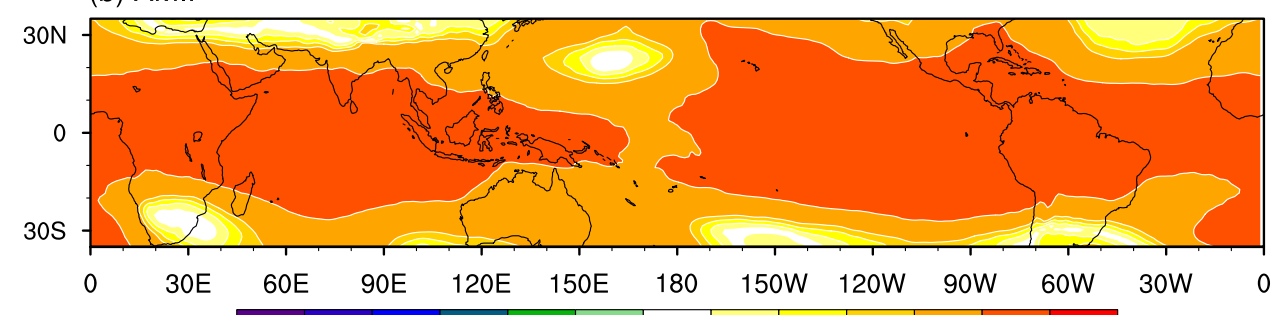

$-1.1-0.9-0.7-0.5-0.3-0.10 .10 .30 .50 .70 .91 .1$

Fig. 9. Regression of $\mathrm{MJJ}(1)$ tropospheric temperature (vertical average from $850 \mathrm{hPa}$ to $200 \mathrm{hPa}$, unit: $\mathrm{k}$ ) on normalized observational $\mathrm{DJF}(0)$ Niño-3.4 SST index in the TIO experiment (a) and the AMIP experiment (b). 


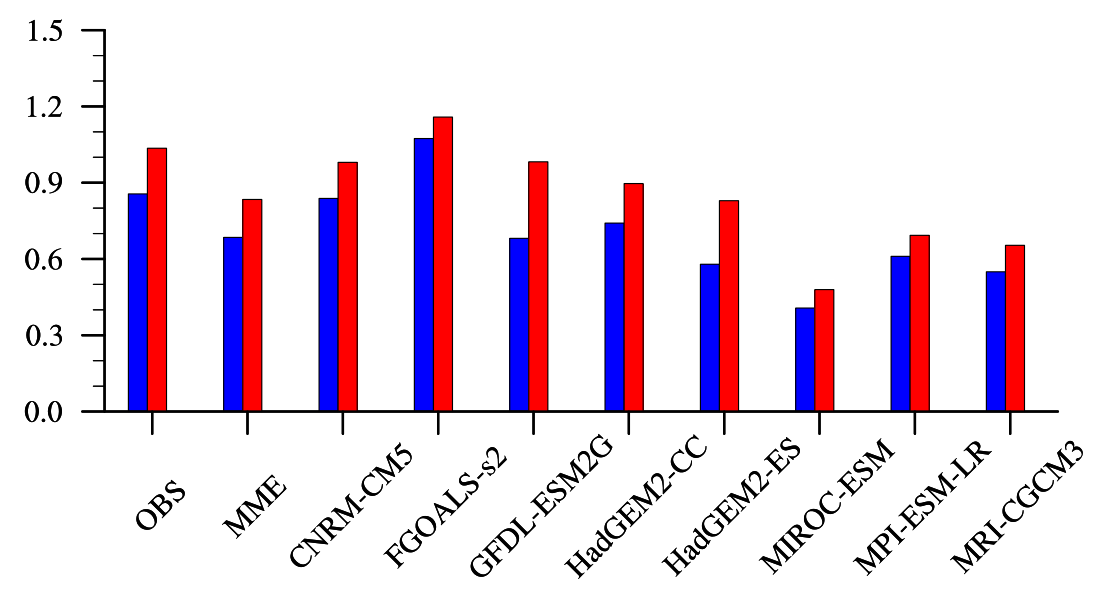

Fig. 10. Standard deviation of the DJF Niño-3.4 SST index in the LC (blue) and HC (red) periods. 
(a) Historical 1870-1919

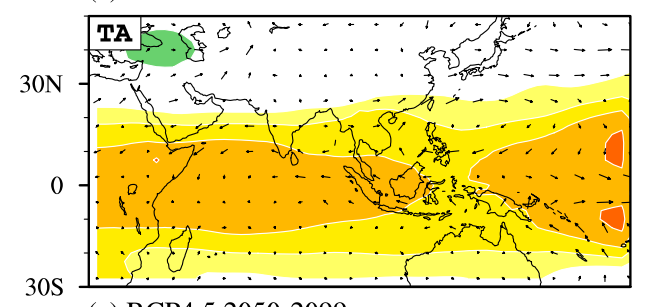

(c) RCP4.5 2050-2099

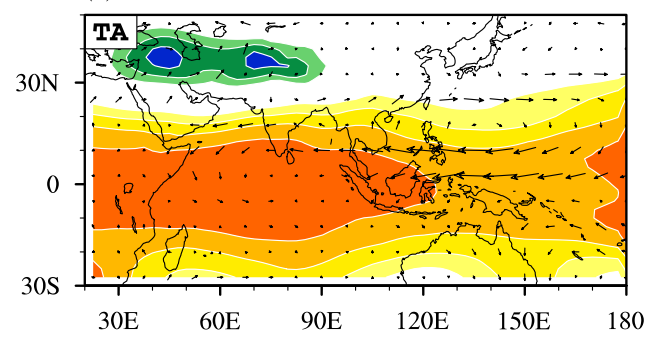

(b) Historical 1951-2000

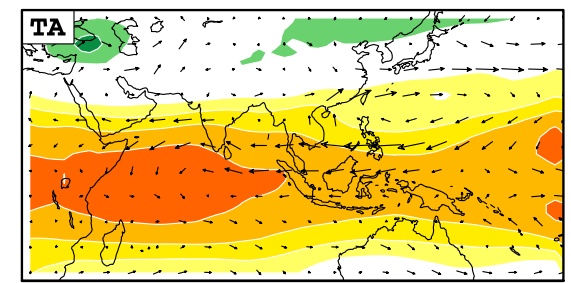

(d) RCP8.5 2050-2099

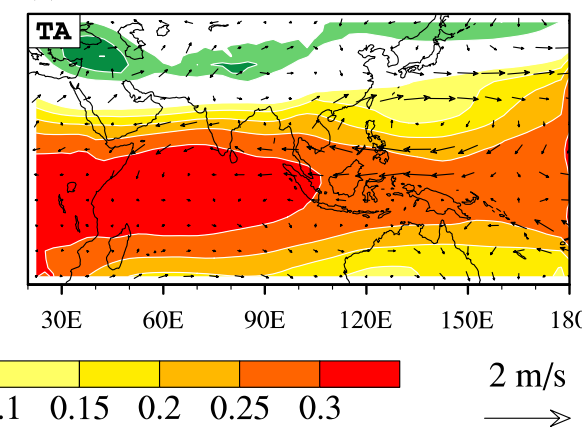

Fig. 11. Multi-Model ensemble mean of MJJ(1) tropospheric temperature anomalies (colors; vertical average from 850 to $200-\mathrm{hPa}$; unit ${ }^{\circ} \mathrm{C}$ ) and $850-\mathrm{hPa}$ winds anomalies (vectors; units m/s) obtained by regression on normalized DJF (0) Niño-3.4 SST index during the period of 1870-1919 in the historical run (a), 1951-2000 in the historical run (b), 2050-2099 in the RCP-4.5 run (c), and 2050-2099 in the RCP-8.5 $\operatorname{run}(d)$. 
(a) Historical 1870-1919
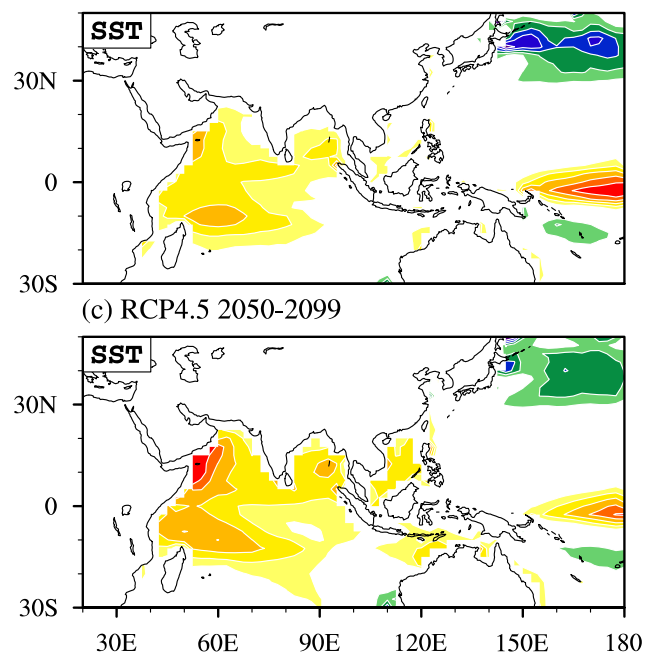

(b) Historical 1951-2000

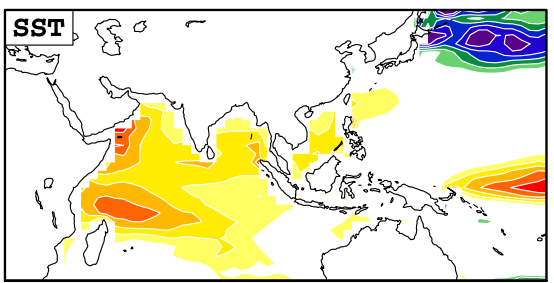

(d) RCP8.5 2050-2099

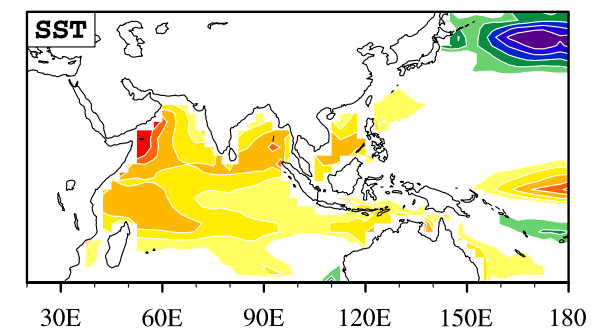

$\begin{array}{llllllllll}-0.3 & -0.25 & -0.2 & -0.15 & -0.1 & 0.1 & 0.15 & 0.2 & 0.25 & 0.3\end{array}$

Fig. 12. Multi-Model ensemble mean of MJJ(1) SST anomalies (colors; unit ${ }^{\circ} \mathrm{C}$ )

obtained by regression on normalized DJF (0) Niño-3.4 SST index during the period of 1870-1919 in the historical run (a), 1951-2000 in the historical run (b), 2050-2099 in the RCP-4.5 run (c), and 2050-2099 in the RCP-8.5 run (d). 
(a) Historical 1870-1919
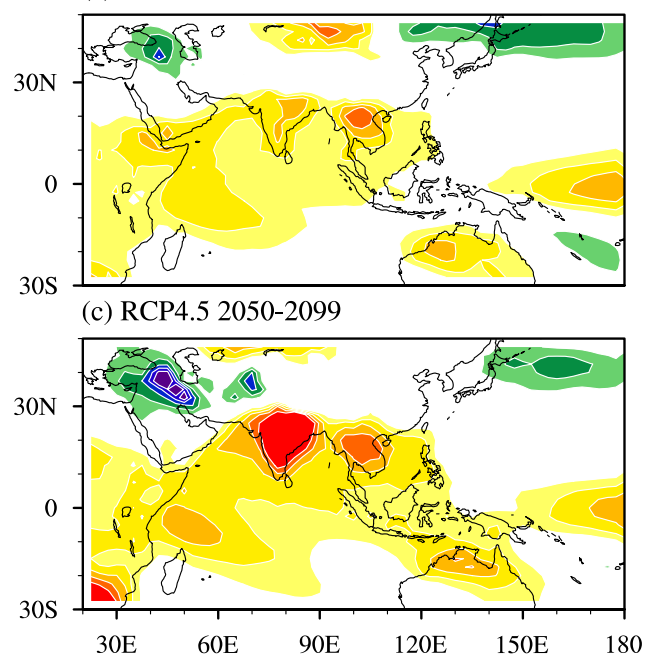

(b) Historical 1951-2000

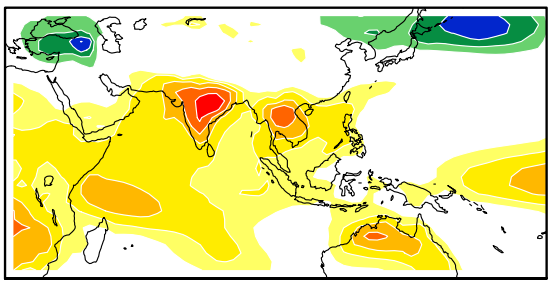

(d) RCP8.5 2050-2099

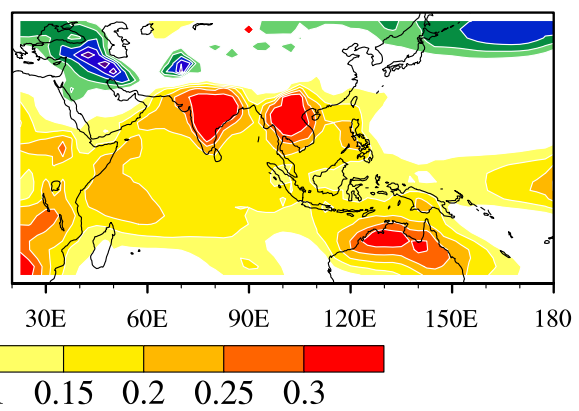

$\begin{array}{llllllllll}-0.3 & -0.25 & -0.2 & -0.15 & -0.1 & 0.1 & 0.15 & 0.2 & 0.25 & 0.3\end{array}$

Fig. 13. Multi-Model ensemble mean of MJJ(1) low-level air temperature anomalies (vertical average from 1000 to $850-\mathrm{hPa}$; unit ${ }^{\circ} \mathrm{C}$ ) obtained by regression on normalized DJF (0) Niño-3.4 SST index during the period of 1870-1919 in the historical run (a), 1951-2000 in the historical run (b), 2050-2099 in the RCP-4.5 run (c), and 2050-2099 in the RCP-8.5 run (d). 
(a) Historical 1870-1919

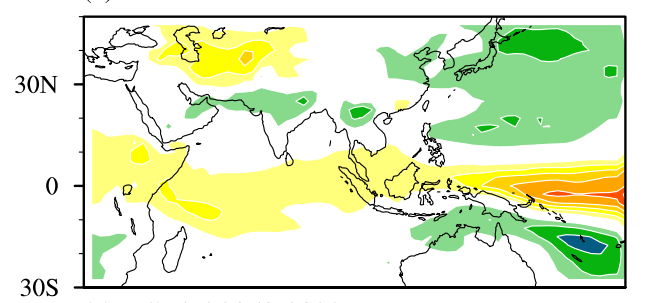

(c) RCP4.5 2050-2099

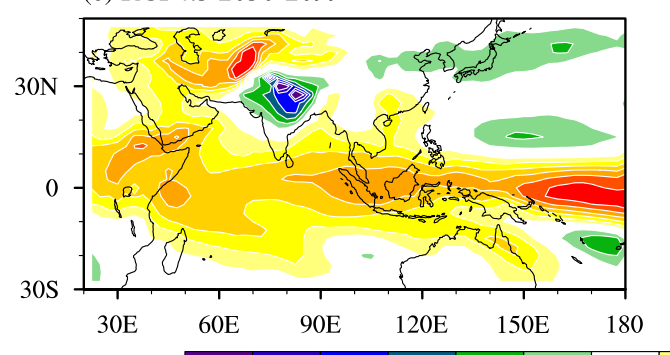

(b) Historical 1951-2000

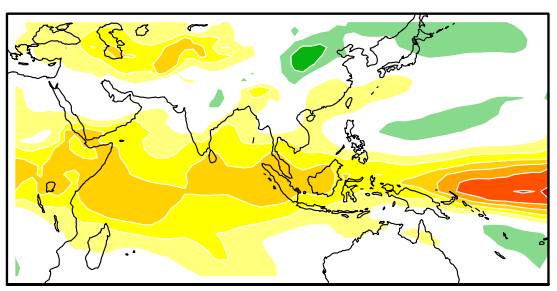

(d) RCP8.5 2050-2099

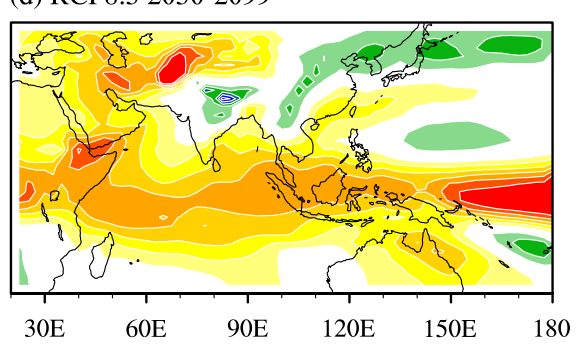

$\begin{array}{llllllllll}-0.3-0.25 & -0.2 & -0.15 & -0.1 & -0.050 .05 & 0.1 & 0.15 & 0.2 & 0.25 & 0.3\end{array}$

Fig. 14. Multi-Model ensemble mean of low-level specific humidity anomalies (vertical average from 1000 to $850-\mathrm{hPa}$; units $\mathrm{g} / \mathrm{Kg}$ ) obtained by regression on normalized DJF (0) Niño-3.4 SST index during the period of 1870-1919 in the historical run (a), 1951-2000 in the historical run (b), 2050-2099 in the RCP-4.5 run (c), and 2050-2099 in the RCP-8.5 run (d). 
(a) Historical 1870-1919

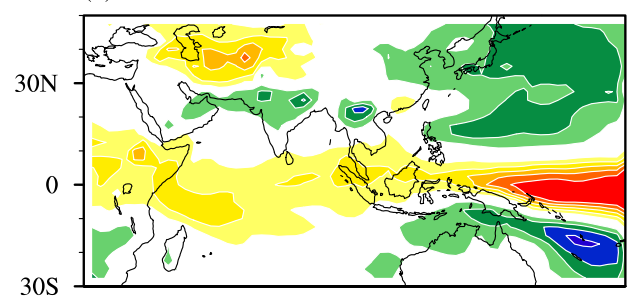

(c) RCP4.5 2050-2099

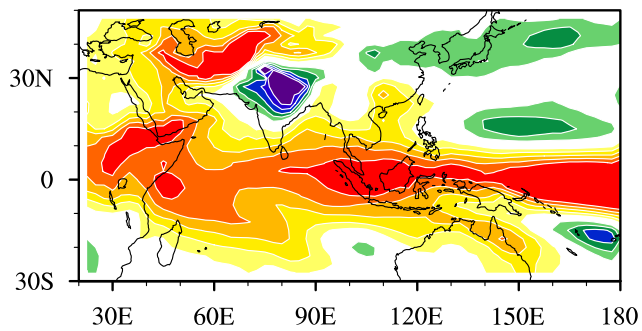

(b) Historical 1951-2000

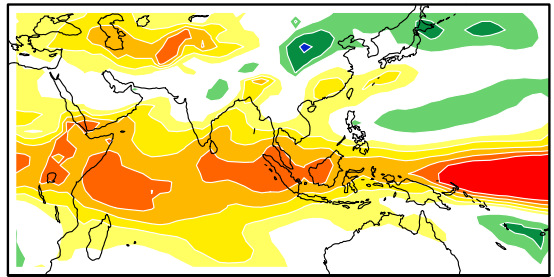

(d) RCP8.5 2050-2099

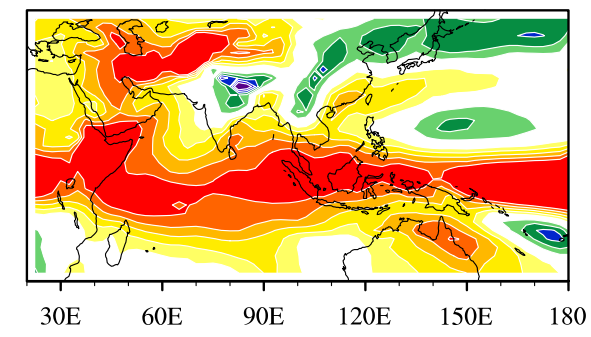

$\begin{array}{llllllllll}-0.5 & -0.4 & -0.3 & -0.2 & -0.1 & 0.1 & 0.2 & 0.3 & 0.4 & 0.5\end{array}$

Fig. 15. Multi-Model ensemble mean of the term of $(L / C p) q^{\prime}$, where $L$ is the latent heat of vaporization, $C p$ denotes the specific heat at constant pressure and $q^{\prime}$ is the MJJ(1) low-level (vertical average from 1000 to $850-\mathrm{hPa}$ ) specific humidity anomaly obtained by regression on normalized DJF (0) Niño-3.4 SST index during the period of 1870-1919 in the historical run (a), 1951-2000 in the historical run (b), 2050-2099 in the RCP-4.5 run (c), and 2050-2099 in the RCP-8.5 run (d). 


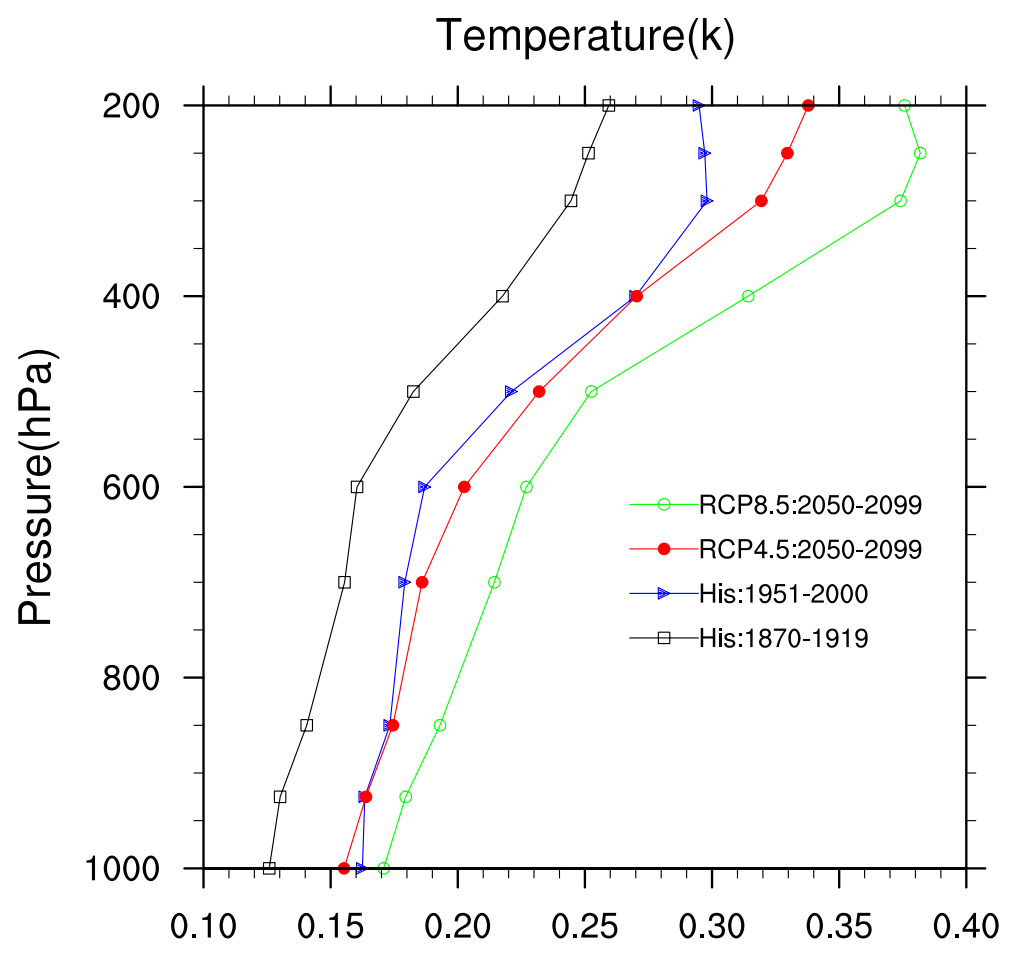

Fig. 16. Multi-Model ensemble mean of MJJ(1) area mean temperature anomalies profile over the $\mathrm{TIO}\left(20^{\circ} \mathrm{S}-20^{\circ} \mathrm{N}, 40^{\circ} \mathrm{E}-100^{\circ} \mathrm{E}\right)$ obtained by regression on normalized DJF (0) Niño-3.4 SST index during the period of 1870-1919 in the historical run (black), 1951-2000 in the historical run (red), 2050-2099 in the RCP-4.5 run (blue) and 2050-2099 in the RCP-8.5 run (yellow). 


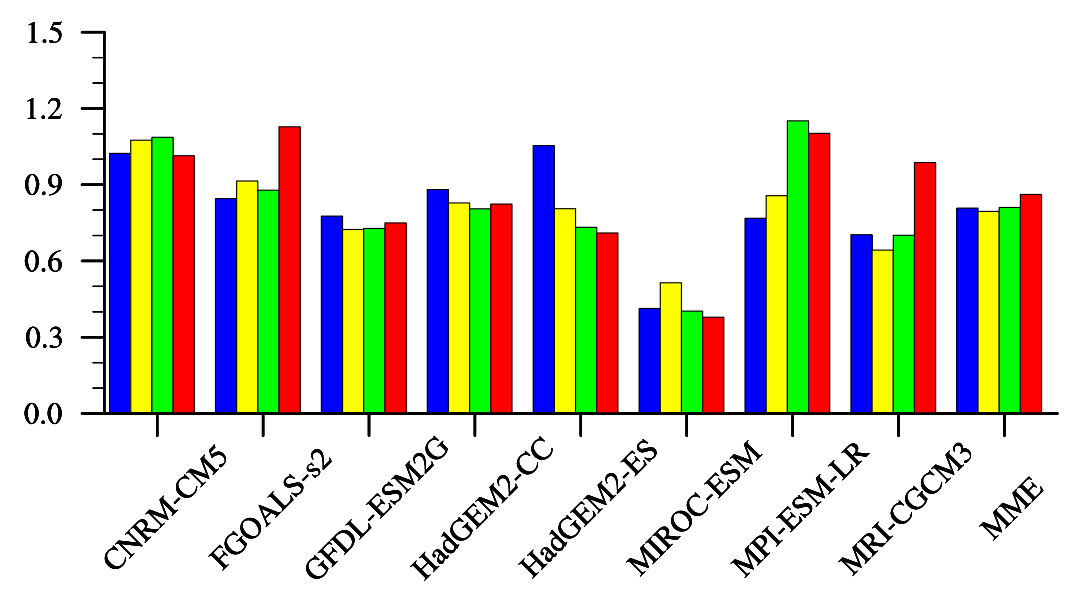

Fig.17. Standard deviation of the DJF Niño-3.4 SST index during the period of 1870-1919 in the historical run (blue), 1951-2000 in the historical run (yellow), 2050-2099 in the RCP-4.5 run (green) and 2050-2099 in the RCP-8.5 run (red). 